\title{
Rabbit haemorrhagic disease (RHD) and rabbit haemorrhagic disease virus (RHDV): a review
}

Joana Abrantes ${ }^{1,2^{*}}$, Wessel van der Loo ${ }^{1}$, Jacques Le Pendu ${ }^{2}$ and Pedro J Esteves ${ }^{1,3}$

\begin{abstract}
Rabbit haemorrhagic disease virus (RHDV) is a calicivirus of the genus Lagovirus that causes rabbit haemorrhagic disease (RHD) in adult European rabbits (Oryctolagus cuniculus). First described in China in 1984, the virus rapidly spread worldwide and is nowadays considered as endemic in several countries. In Australia and New Zealand where rabbits are pests, RHDV was purposely introduced for rabbit biocontrol. Factors that may have precipitated RHD emergence remain unclear, but non-pathogenic strains seem to pre-date the appearance of the pathogenic strains suggesting a key role for the comprehension of the virus origins. All pathogenic strains are classified within one single serotype, but two subtypes are recognised, RHDV and RHDVa. RHD causes high mortality in both domestic and wild adult animals, with individuals succumbing between 48-72 $\mathrm{h}$ post-infection. No other species has been reported to be fatally susceptible to RHD. The disease is characterised by acute necrotising hepatitis, but haemorrhages may also be found in other organs, in particular the lungs, heart, and kidneys due to disseminated intravascular coagulation. Resistance to the disease might be explained in part by genetically determined absence or weak expression of attachment factors, but humoral immunity is also important. Disease control in rabbitries relies mainly on vaccination and biosecurity measures. Such measures are difficult to be implemented in wild populations. More recent research has indicated that RHDV might be used as a molecular tool for therapeutic applications. Although the study of RHDV and RHD has been hampered by the lack of an appropriate cell culture system for the virus, several aspects of the replication, epizootology, epidemiology and evolution have been disclosed. This review provides a broad coverage and description of the current knowledge on the disease and the virus.
\end{abstract}

\section{Table of contents}

1. Natural history

2. Aetiological agent

3. Clinical signs and lesions

4. Epidemiology

5. Virus life cycle

6. Mechanisms of resistance to RHD

7. Genetic diversity/RHDV evolution

7.1. Pathogenic RHDV

7.2. Non-pathogenic rabbit calicivirus

8. Host-virus co-evolution

9. Prevention, control and vaccination

10. Therapeutic applications of RHDV

11. Conclusions

12. List of abbreviations

* Correspondence: jabrantes@mail.icav.up.pt

'CIBIO/UP, Centro de Investigacao em Biodiversidade e Recursos Geneticos/ Universidade do Porto, Campus Agrario de Vairao, 4485-661 Vairao, Portugal Full list of author information is available at the end of the article
13. Competing interests
14. Authors' contributions
15. Acknowledgements
16. References

\section{Natural history}

In the 1980s, the European rabbit populations were devastated by a new viral disease characterised by being extremely lethal and highly contagious in both domestic and wild rabbits (Oryctolagus cuniculus). The first outbreak of this new disease, designated as rabbit haemorrhagic disease (RHD), was noticed in 1984 in the Jiangsu Province of the People's Republic of China within a group of commercially-bred Angora rabbits imported from Germany [1]. In less than a year, RHD killed 140 million domestic rabbits in China and spread over an area of $50000 \mathrm{~km}^{2}[1,2]$. Korea was the next country to report RHD outbreaks which were associated with rabbit fur importation from China [3]. The disease

\section{C) Biomed Central}


then appeared in Europe and was first reported in Italy in 1986 [4] from where it spread to the rest of Europe, becoming endemic in several countries. In the Iberian Peninsula, where European rabbits originated and where they constitute a key species of the ecosystem [5], the first outbreaks date back to 1988 for Spain [6] and to 1989 for Portugal [7] and caused severe reduction of wild populations $[8,9]$. At the same time, domestic populations from several countries in North Africa experienced RHD outbreaks [10]. In the Americas, the first outbreaks were recorded in 1988 in Mexico following the importation of rabbit products from China [11]. Nevertheless, Mexico is currently the only country that has managed to successfully eradicate RHD with the last outbreak having occurred in 1992 [11]. This successful eradication of the disease might correlate with the absence of natural populations of wild European rabbits. North America recorded the first outbreak only in 2000 and experienced a few additional outbreaks since then [12]. As the virus spread worldwide, naturally occurring RHD outbreaks were reported in geographically distant regions, such as Cuba, Uruguay and Reunion Island [13,14].

RHD causes important economic losses in the rabbit meat and fur industry and has a significant negative ecological impact among wild rabbit populations and indirectly on its dependant predators $[2,11,15,16]$. In Australia and New Zealand, where the rabbit is considered an important agricultural pest, as well as a major threat to the endemic wildlife flora and fauna $[17,18]$, rabbit haemorrhagic disease virus (RHDV) was soon considered as an agent for rabbit control [19]. In 1991, a scientific research program was initiated in laboratory under quarantine measures to assess the host specificity and efficacy of the RHDV Czech reference strain (Czech V351) as a biocontrol agent. After approval of the Australian authorities, RHDV was released in the Wardang Island in Spencer Gulf, South Australia. Despite the rigorous quarantine measures, in 1995 RHDV escaped from the island, possibly transported by insects or air currents and reached the mainland [20]. In less than two years, it became established across southern Australia. The initial spread was estimated to be $50 \mathrm{~km}$ per week. In some areas a reduction of more than $95 \%$ of the wild rabbit populations was observed, particularly in the more arid regions [21]. In New Zealand, after a careful investigation on the benefits and risks of introducing RHDV, the government decided not to introduce the virus [19]. The virus was later illegally introduced by landholders [22]. Posterior characterisation of the New Zealand virus showed it to be similar to the Czech V351 strain introduced in Australia suggesting that it was imported from there [23].

Nowadays, RHDV outbreaks still occur on almost all continents and cause significant mortality rates, being endemic in most parts of Europe, Asia, and parts of Africa, Australia and New Zealand. As a general trend, it seems that in areas where the European rabbit is historically present as wild populations, RHDV is also present and endemic. In contrast, in regions where the European rabbit is mainly present as a domestic or industrial animal, the occurrence of RHDV (epidemics or rare outbreaks) seems to be correlated with rabbit colony number and density.

\section{Aetiological agent}

Early efforts to classify RHDV were erratic, mostly due to its non-cultivable nature. Initially suspected to be a picornavirus [24], a parvovirus [25] and a parvo-like virus [2], it was finally assessed in the early 1990s as a member of the Caliciviridae family [26-30].

The International Committee on Taxonomy of Viruses (ICTV) recognises four genera in the Caliciviridae family: Lagovirus, Vesivirus, Norovirus and Sapovirus. Three more genera were recently proposed as part of this family: Nabovirus or Becovirus [31], Recovirus [32] and Valovirus [33], but are not yet recognised by the ICTV. Caliciviruses infect a broad range of animals, including humans, and cause a variety of diseases, such as gastroenteritis by Norovirus and Sapovirus, haemorrhagic disease by Lagovirus, and vesicular lesions, respiratory infections and reproductive failure by Vesivirus. The Lagovirus genus comprises both RHDV and European brown hare syndrome virus (EBHSV), a virus first detected in Sweden in the early 1980s prior to the first RHDV outbreak [34] which affects hare species (Lepus europaeus and Lepus timidus). European brown hare syndrome (EBHS) is closely related to RHD with regards to clinical signs, pathological and histopathological alterations, mortality rates, virion morphology and antigenicity, but cross-species infection and cross-species protection could not be obtained in a reproducible way. Despite the similarities, RHDV and EBHSV represent distinct agents, infecting different species although causing similar diseases [35-40].

As in other caliciviruses, RHDV virions are small sized (between 35-40 nm of diameter) and non-enveloped. The capsid, which forms the protein layer that protects the RNA molecule, is composed of 90 arch-like dimers of the capsid protein which form 32 cup-shaped depressions (calix in Latin for cup or chalice as the root for the family name Caliciviridae) arranged in a $\mathrm{T}=3$ icosahedral symmetry $[41,42]$. Each capsid monomer consists of a shell (S) domain which is buried and comprises the $\mathrm{N}$-terminal connected by a hinge to the protruding $(\mathrm{P})$ domain that encompasses the $\mathrm{C}$-terminal region and is exposed on the surface [39-41,43-46]. The $\mathrm{P}$ domain can be further subdivided into the subdomains P1 (stem of arch) and P2 (top of arch) [47]. The 
subdomain P2, located at the most exposed region of the capsid, displays the greatest genetic variation. This variation is probably, at least in part, due to selection pressure because host antibodies recognise and target regions located in this subdomain $[43,44,48]$. In order to avoid this recognition and the inherent selective pressure, these regions tend to evolve faster $[49,50]$ which results in an increase of the genetic variability and hence, of the antigenic variation. In addition, in noroviruses, the P2 domain has been shown to contain the carbohydrate-binding domain, contributing to several more conserved amino acids [51-53]. By analogy, this should also apply to RHDV.

Sporadically, in rabbits affected by subacute or chronic forms of RHD with long clinical courses, it is possible to detect a second type of virus particle, the RHDV corelike particles (CLP), also referred to as smooth particles or s-RHDV [35]. These particles are found in large amounts in the liver and spleen [54] and present unique characteristics when compared to RHDV particles: a smooth surface due to the lack of the cup-shaped depressions; a smaller diameter of 25-29 nm; a molecular weight of $28-30 \mathrm{kDa}$ indicating that CLP correspond to the N-terminus (the buried shell domain) of the capsid; no haemagglutinating activity, most likely as the result of the absence of the C-terminus, but presenting reactivity with sera from RHDV convalescent rabbits and monoclonal antibodies directed towards the Nterminal part of the RHDV capsid [35,54-56]. CLP seem to be associated with the appearance of specific antiRHDV IgM [54]. Indeed, these particles have been suggested to result from the degradation of the RHDV-IgM immune-complexes formed during the humoral response [54]. Although defective gene expression has been suggested to be at the genesis of CLP [55], recent data indicate that CLP directly derive from intact virions with dissociated protrusion [45].

RHDV virions contain the genomic RNA (gRNA) and an additional RNA species with $2.2 \mathrm{~kb}$ designated subgenomic RNA (sgRNA), which is collinear with the 3' end of the genomic RNA [26,57]. Subgenomic RNA usually contributes to the production of high levels of products required during the intermediate and late stages of infection (e.g. structural proteins) [58]. For RHDV, these comprise the capsid protein and VP10 [59-61]. Both the genomic and subgenomic RNA are polyadenylated at the 3' end and at their 5' region they are covalently linked through a Tyr-21 residue to the VPg (virus genome-linked) protein [62]. The genomic RNA consists of a positive-sense single-stranded molecule of 7437 nucleotides consisting of two slightly overlapping open reading frames (ORF): ORF1, comprising nucleotides 10 to 7044 and ORF2, comprising nucleotides 7025 to 7378 [26]. ORF1 encodes a large polyprotein of ca. $257 \mathrm{kDa}$ [26] which is cleaved into the mature non-structural proteins and a major structural protein, the capsid protein, by post-translational proteolytic processing by a virus-encoded trypsin-like cysteine protease (Figure 1) [57,63-65]. Some of these proteins derive from larger precursors that result from further post-translational modifications of the precursor proteins [57,64]. The biological role of some of the non-structural proteins encoded by the genome of caliciviruses has been elucidated by relying on previous knowledge gathered from

Genomic RNA $(\sim 7.4 \mathrm{~kb})$
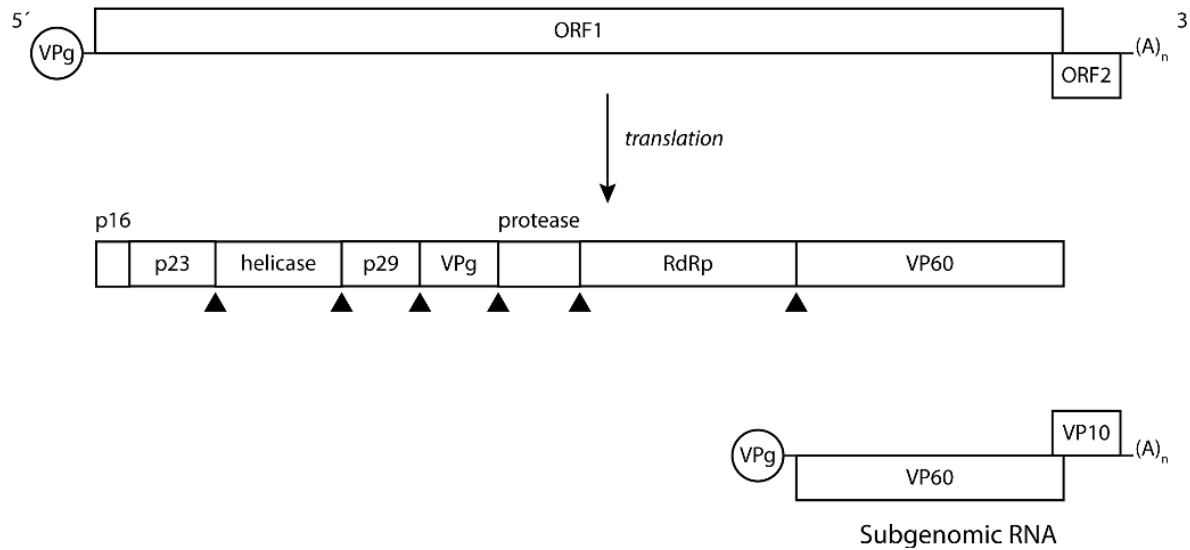

Figure 1 Genomic organization of RHDV. The genome of RHDV is composed of two narrowly overlapping ORFs, ORF1 and ORF2. ORF1 codes for a polyprotein that is cleaved by the virus-encoded trypsin-like cysteine protease (arrowheads) and originates the major structural protein for the capsid (VP60) and the non-structural proteins p16, p23, helicase, p29, VPg, protease and RdRp. ORF2 codes for a minor structural protein, VP10. A subgenomic mRNA encoding both the structural proteins VP60 and VP10 can also be found in viral particles. Both the genomic and subgenomic RNA are polyadenylated at their $3^{\prime}$ end and have the virus-encoded protein, VPg, covalently attached to their $5^{\prime}$ end. 
members of the closely related Picornaviridae family $[26,64,65]$. For RHDV, two proteins involved in the replication of the viral RNA, a helicase and an RNAdependent RNA polymerase ( $R \mathrm{dRp})$, and a protease responsible for the proteolytic processing of the large polyprotein, have been characterised [63,66,67]. $R d R p$ has been shown to also catalyse VPg uridylation $[62,68]$ while a role in translation has been suggested for VPg [e.g. [69]]. The function of the RHDV non-structural proteins p16, p23 and p29 remains to be assessed. VP10, a minor structural protein encoded by the 3 'end of gRNA and sgRNA in a different reading frame (ORF2), was recently shown to increase the levels of virus replication and to promote apoptosis [70]. In addition, its ability to downregulate the expression of VP60 was demonstrated [71]. Together, this suggests that VP10 might regulate virus replication and virion release from infected host cells [71].

\section{Clinical signs and histopathological lesions}

The incubation period of the disease ranges between 1 to 3 days and rabbits usually succumb within $12 \mathrm{~h}$ to 36 $\mathrm{h}$ after the onset of fever $\left(>40^{\circ} \mathrm{C}\right)$. Depending on the clinical evolution of the disease, three different clinical courses can occur [38,72]. In the peracute form, infected animals show no clinical signs and die suddenly. Acute infections are accompanied by anorexia, apathy and congestion of the palpebral conjunctiva and neurologic symptoms such as opisthotonos, excitement, paralysis and ataxia may also be observed. There are occasionally some respiratory signs (tracheitis, dyspnea and cyanosis) and a foamy and bloody nasal discharge; lacrimation, ocular haemorrhages and epistaxis can also occur. Subacute forms of the disease present similar, but milder clinical symptoms and most rabbits survive. Rabbits experiencing subacute infections develop antibodies against RHDV which confer protection upon re-infection [73]. In addition, it has been reported that during an outbreak of RHD, a low percentage of rabbits may experience a chronic form of the disease with symptoms including a severe and generalised jaundice, anorexia and lethargy [35]. These animals tend to die 1-2 weeks later [54], but animals that overcome the disease present a potent seroconversion [35]. Interestingly, this form of the disease has been shown to be associated with the presence of RHDV core-like particles [35,55].

The liver, lung and spleen are the primary target tissues of RHDV. The major histopathological lesions found at necropsy are acute hepatitis due to liver cell loss as the result of RHDV-induced apoptosis, and splenomegaly [74,75]. Haemorrhages and congestions can be seen in several organs, particularly in the lungs, heart and kidneys, as a result of a massive disseminated intravascular coagulation (DIC) which is usually the cause of death [76]. Depletion of both B and T lymphocytes in the liver and the spleen accompanies the disease and accounts for an impairment of the immune response $[72,77]$ and a fatal progression of the disease within 2-3 days. In contrast, resistant rabbits develop high titres of $\operatorname{IgM}$ (and then of $\operatorname{IgA}$ and of $\operatorname{IgG}$ ) already at day $3 \mathrm{pi}$, thus presenting an effective humoral immune response [54]. Table 1 presents a summary of the histopathological alterations that can be observed upon RHDV infection.

\section{Epidemiology}

The possible routes for transmission of the disease are the oral, nasal, conjunctival and parenteral, as bloodfeeding insects have also been shown to be efficient mechanical vectors $[72,78]$. Transmission of RHDV may occur through direct contact with an infected animal, since infected rabbits may shed viral particles in their secretions and excretions [79], or indirectly by means of fomites-contaminated food, bedding, water, clothing, cages and equipment [19]-or vector-borne transmission

Table 1 Pathological and histopathological lesions $[16,77,222,241,243]$

\begin{tabular}{|c|c|}
\hline Organ & Lesions \\
\hline Liver & $\begin{array}{l}\text { Enlarged with marked lobular pattern, yellow-grey } \\
\text { colour, brittle, circumscribed infiltration with } \\
\text { granulocytes, degenerative alterations of } \\
\text { hepatocytes compatible with apoptosis (extensive } \\
\text { vacuolization, severe alterations in the } \\
\text { mitochondrial structure, karyopyknosis and } \\
\text { karyolysis) activation of Kupffer cells, leukopenia }\end{array}$ \\
\hline Trachea & $\begin{array}{l}\text { Hyperaemia of mucous membrane, petechial or } \\
\text { diffuse haemorrhages, may be filled with bloody } \\
\text { foam }\end{array}$ \\
\hline Lung & $\begin{array}{l}\text { Hyperaemia, pulmonary oedema, intra-alveolar and } \\
\text { perivascular haemorrhages, sometimes slight } \\
\text { catarrhal bronchiolitis, proliferation of lymphocytes }\end{array}$ \\
\hline Kidneys & $\begin{array}{l}\text { Enlargement with spotted dark red coloration, } \\
\text { hyperaemia, haemorrhages within glomerular } \\
\text { loops and renal medulla, hyaline thrombi, dilated } \\
\text { tubuli, lymphocytic infiltration, degeneration of } \\
\text { tubular epithelium }\end{array}$ \\
\hline Spleen & $\begin{array}{l}\text { Enlargement (splenomegaly), spotted dark red } \\
\text { colorations, hyperaemia, occasionally karyorrhexis } \\
\text { within follicles, hemosiderosis, leukopenia }\end{array}$ \\
\hline Digestive tract & $\begin{array}{l}\text { Contents usually normal, occasional enteritis, } \\
\text { subserous haemorrhages }\end{array}$ \\
\hline $\begin{array}{l}\text { Chest and } \\
\text { abdominal cavity }\end{array}$ & $\begin{array}{l}\text { Small amounts of serous, occasionally bloody } \\
\text { exudate, sometimes subserous haemorrhages }\end{array}$ \\
\hline Muscles & $\begin{array}{l}\text { Anaemia in the area of the thighs, petechiae in } \\
\text { the heart muscle, focal necrosis in myocardium, } \\
\text { degenerative alterations, hemosiderosis }\end{array}$ \\
\hline $\begin{array}{l}\text { Central Nervous } \\
\text { System }\end{array}$ & $\begin{array}{l}\text { Congestion of cortical vessels, dilated vessels in } \\
\text { the area of the pia mater of the cortex and } \\
\text { cerebellum, hyperaemia, small haemorrhages in } \\
\text { the cortex, occasionally non-purulent } \\
\text { encephalomyelitis with lymphocytic infiltration }\end{array}$ \\
\hline
\end{tabular}


by scavenging mammals, birds and insects [e.g. $[78,80,81]]$. The natural doors for viral entry have been suggested to be located in the upper respiratory and digestive tract $[16,82]$. In natural infections, the faecaloral route is considered the preferential mode of transmission $[10,11]$.

In the field, carcasses of RHDV-infected rabbits may be a major source for viral spreading since the virus seems to be highly resistant and stable when exposed to harsh environmental conditions. Indeed, carcasses of RHDV-infected rabbits exposed to environmental conditions have been found to contain viable viral particles for up to three months $[83,84]$. This ability is paramount for the epidemiology of RHD and supports the importance of indirect routes in transmission. Environmental factors have also been suggested to impact on the effectiveness of RHD in rabbit populations [reviewed in [20]]. Temperature and humidity seem to be the most important climate variables. Indeed, in Australia, mortality rates due to RHD are higher in arid and semiarid inland areas than in moist coastal regions experiencing milder temperatures and the disease becomes active during the breeding season, peaks in early spring and is absent in the summer [85]. Climate variables might contribute to the geographic and seasonality observed for the RHDV outbreaks by affecting the abundance and activity of the vectors involved in RHDV transmission [reviewed in [20]]. Other non-climatic factors have also been suggested to contribute to the variable pattern of the impact of RHD in rabbit populations such as the timing of the breeding season, the presence of a related and protective RHDV-like calicivirus in rabbit populations or the negative interaction of the myxomatosis outbreaks in the populations [reviewed in [86]]. In addition, modelling studies indicated that population dynamics and spatial structure may greatly influence disease impact and host-virus co-evolution $[87,88]$.

Caliciviruses occur in a wide range of animals apart from rabbits, which include mustelids (minks and skunks), reptiles, cattle, felids (cats and cheetahs), dogs, humans, chimpanzees, pigs and sea mammals (sea lions, seals, walrus, whales, and dolphins), but they are usually restricted to their primary host and closely related species [89]. Indeed, rabbits and hares are the only hosts for the RHDV and EBHSV lagoviruses, respectively. Other leporid species have been shown not to be susceptible to RHDV [11]. Additionally, several non-host species from the Australian fauna, including domestic, feral animals and wildlife, were assessed for susceptibility to RHDV. No viral replication could be detected with an extensive panel of tests which included clinical observations, pathology, electron microscopy, virology and serology, reinforcing the idea that susceptibility to RHDV is restricted to the European rabbit (Oryctolagus cuniculus) [90]. Both subspecies of the European rabbit, O. c. cuniculus and O. c. algirus, seem equally susceptible to RHDV [91]. Interestingly, antibodies against RHDV had been found in animals that live in sympatry with rabbit populations infected with RHDV $[81,92,93]$ and, more recently, RHDV RNA was isolated from sympatric wild micromammals opening the possibility of other species being involved in the epidemiology of the disease [94].

\section{Virus life cycle}

In adult rabbits, the targets of the initial stages of the virus life cycle have been determined. Indeed, viral antigens are detected in the liver within the first hours following infection with RHDV with viral replication occurring in the cytoplasm of hepatocytes located mostly in centriacinar areas [30,74,95-98]. The number of infected hepatocytes clearly increases in the course of the disease, reaching a maximum between 36-48 $\mathrm{h}$ [95-97]. Detection of viral antigens in Kupfer cells has also been reported $[74,98]$ associated with viral replication [98]. Extrahepatic presence of the virus has also been observed, but some discrepancies exist between the different studies since different techniques had been employed. Nevertheless, viral antigens have been detected in the spleen, in particular in the macrophages located in the red pulp [96-98], kidney [96], and alveolar macrophages in the lungs. It has been suggested that the presence of replicating virus in alveolar macrophages, which are in contact with the bloodstream, might be important for initial virus dissemination, and later when the virus reaches the liver, Kupfer cells may be important for spreading the infection into other organs [98].

In contrast, viral dissemination in young resistant rabbits is far unclear. Viral antigens have been detected in hepatocytes from experimentally-infected 2 -week old rabbits [99], but most studies were only able to detect them in rabbits older than 4-weeks [96,100]. Viral antigens were found to be scattered and present in only a small percentage of cells. Nevertheless, this suggests that some hepatocytes in young (resistant) rabbits are able to support viral replication, but that major changes must occur in the liver to support a full infectious process. In addition, clearance of the virus seems to be extremely rapid as no viral antigens were detected after day 4 pi [100]. The presence of the virus in other organs has not been fully assessed.

However, as with most caliciviruses, understanding the interaction between RHDV and its host has been hampered by the lack of a suitable in vitro culture system. Consequently, studies on the pathogenesis of caliciviruses have relied on the ability of the capsid protein to self-assemble into virus-like particles (VLP) when 
expressed in insect cells. These particles have the advantage of being morphologically and antigenically indistinguishable from native virions, despite being devoid of viral RNA [59,101-105]. RHDV VLP strongly agglutinated human adult erythrocytes as the result of binding to glycolipid ligands present on the erythrocyte surfaces [72]. These ligands must develop with age since VLP did not agglutinate erythrocytes from human umbilical cords or foetuses presenting no agglutination [106]. Subsequent studies revealed that several caliciviruses use the carbohydrate moiety of host-cell histo-blood group antigens (HBGA) for attachment (e.g. ABH/O and Lewis antigens) initiating their replication cycle (Figure 2) [82,107-115]. Histo-blood group antigens are complex glycans either attached to proteins or lipids present on the surface of epithelial cells and erythrocytes, either as free oligosaccharides in biological fluids (milk, saliva, blood and intestinal contents). HBGA are formed by the sequential addition of monosaccharides to an oligosaccharide precursor chain attached to the cell glycans. This process, designated glycosylation, is catalysed by glycosyltransferase enzymes with specific substrate affinity and by a defined linkage [116]. Several genes encode the glycosyltransferases resulting in ABO, Lewis and secretor polymorphic phenotypes (Figure 3 ).

RHDV was shown to bind to the HBGA H type 2, A type 2 and B type 2 oligosaccharides [82,117]. These structures were shown to be present on the surface of the epithelial cells of the upper respiratory and digestive tracts that the virus first encounters when infecting the host and therefore where doors for virus entry are most likely located $[16,82]$. Synthesis of $H$ type 2 requires the

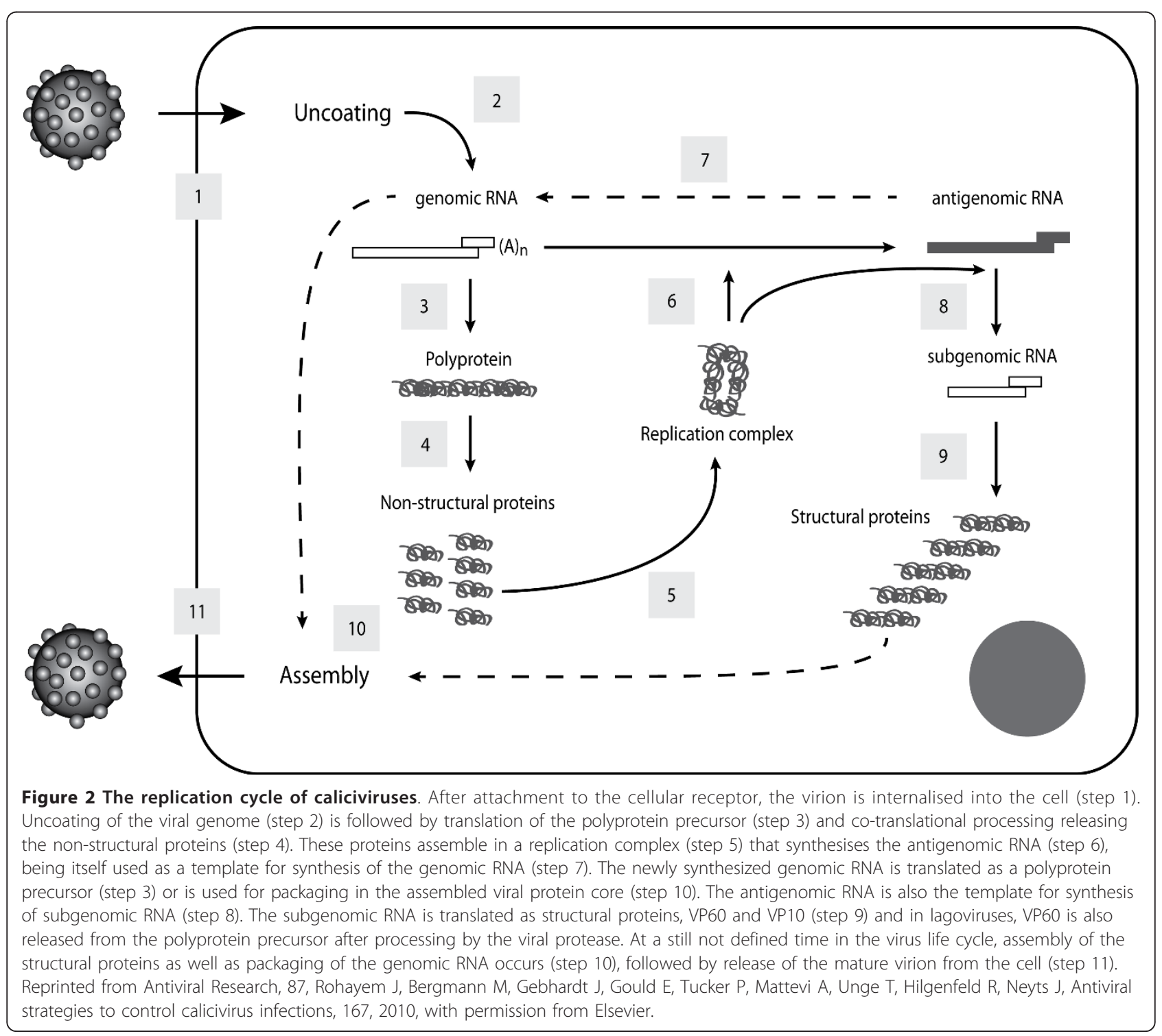




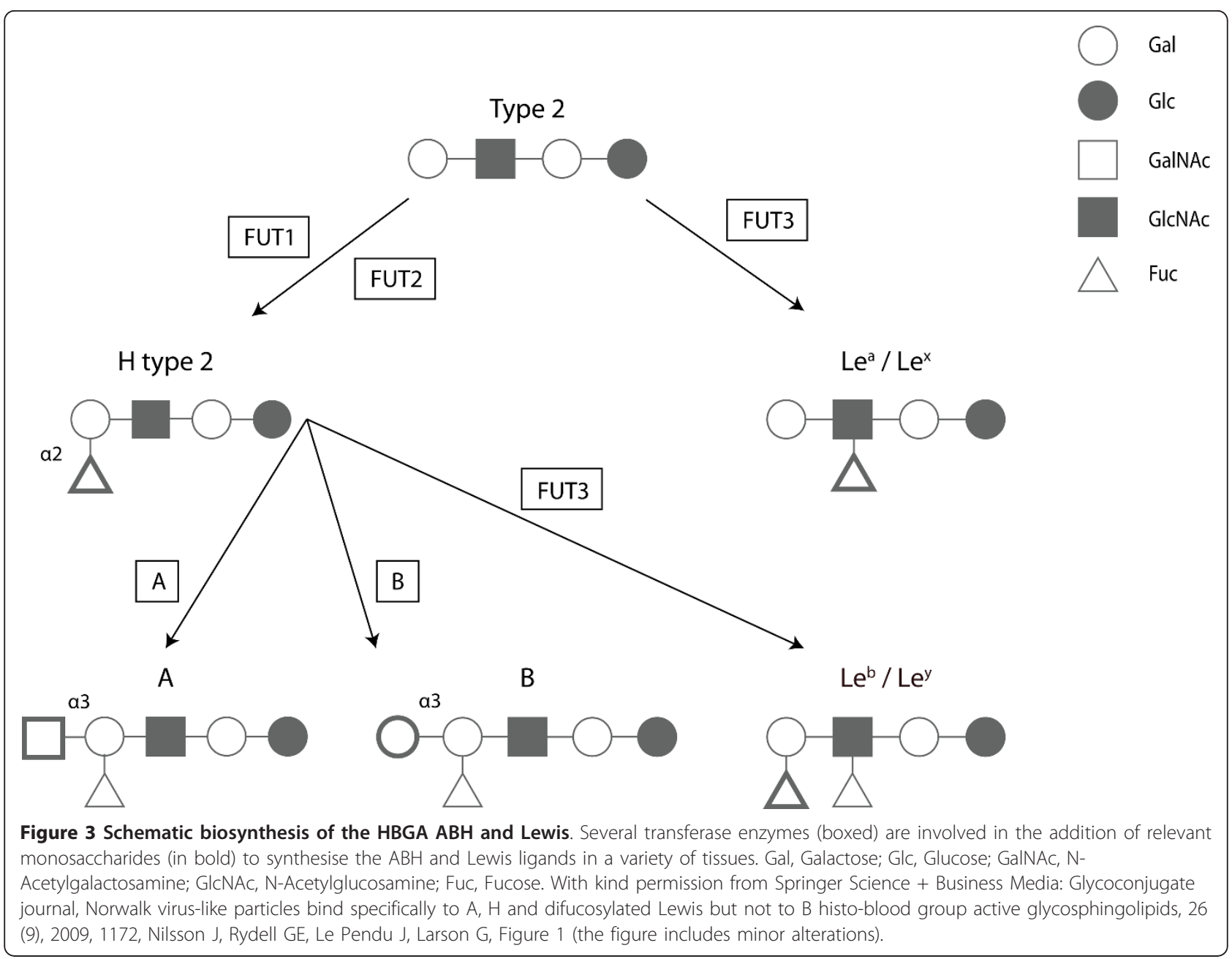

addition of a fucose residue, the minimal structural epitope [118], in $\alpha 1,2$ linkage to a precursor. This reaction is catalysed by an $\alpha 1,2$-fucosyltransferase which in rabbits is encoded by three functional genes, Fut1, Fut2 and $\operatorname{Sec} 1$ that have undergone multiple events of gene conversion during evolution [119]. Synthesis of the A and $B$ type 2 antigens involves the addition of either a $\mathrm{N}$-acetylgalactosamine or a galactose residue in $\alpha 1,3$ linkage to the $\mathrm{H}$ type 2 trisaccharide in a reaction catalysed by an $\alpha 1,3-\mathrm{N}$-acetylgalactosaminyltransferase or an a1,3-galactosyltransferase (A or B transferases), respectively. In rabbits, the $A B O$ blood group locus is largely unresolved, but preliminary data suggest that at least 6 $A b o$ genes exist in the genome, arranged in tandem (K Nyström and J Le Pendu, personal communication).

Following the attachment of RHDV to the cell surface, internalisation, by an unknown mechanism, and desencapsidation occur, leading to the release of the viral genome into the cytoplasm. The virus life cycle then proceeds to the translation of the polyprotein precursor encoded by the ORF1 of the viral genome through interaction with the host cellular machinery. The gRNA and the sgRNA covalently-linked VPg uses the cellular translation machinery, positioning the ribosome at the initiation codon AUG without ribosome scanning and initiating translation $[69,120]$. Post-translational proteolytic processing by the viral gRNA encoded protease cleaves the polyprotein precursor into the mature nonstructural proteins and, in RHDV, into the capsid protein VP60 [57]. The non-structural proteins, helicase and $\mathrm{RdRp}$, then form a replication complex synthesising a complementary negative-sense RNA from the genomic RNA which is used as a template for the synthesis of gRNA and the sgRNA [reviewed in [121]]. The resulting RNA can either be de novo translated or packaged into viral particles that will be released from the infected cell. The mechanism used by RHDV for dissemination of the viral progeny is still unclear, but the ability of VP10 to induce apoptosis may suggest a role in programmed cell death in virion release and dissemination $[70,95]$.

Translation of the RHDV ORF2 produces VP10 through a unique mechanism of reinitiation after 
termination of translation of the preceding major capsid protein [122]. This mechanism, although not fully understood, is dependent on the RNA sequence located upstream of the start/stop site, designated TURBS (termination upstream ribosomal binding site), but it is independent on the presence of the AUG initiation codon. Two critical motifs for VP10 expression have been identified within TURBS: motif 1 , which is highly conserved among caliciviruses and shows complementarity with a short sequence in the $18 \mathrm{~S}$ rRNA thus suggesting an interaction between the viral RNA and the ribosomal $18 \mathrm{~S}$ rRNA, and motif 2 , which is believed to be involved in the correct positioning of the ribosome at the translational start site $[122,123]$.

\section{Mechanisms of resistance to RHD}

The lack of a cell culture system has been hampering the study of RHDV pathogenesis and, as a consequence, the mechanisms of resistance to the disease. The indirect strategies that have been employed for the study of the pathogenesis of RHDV allowed the identification of the HBGA $\mathrm{H}$ type 2 as an attachment factor for RHDV [82]. In humans, identification of alleles at the $A B O$, FUT2 and FUT3 loci that generate failure to express antigens recognised by different human Norovirus strains and that confer resistance to infection led to the search of such alleles in the $\alpha 1,2$-fucosyltransferase genes in adult rabbits [124]. This represented the first study on the genetic mechanisms underlying resistance to RHDV. A link between a rabbit allele at the $\alpha 1,2-$ fucosyltransferase gene Sec1, that also intervenes in the $\mathrm{H}$ type 2 synthesis, and survival to a devastating RHDV outbreak was demonstrated [124]. This Sec1 allele encoded a weakly functional $\alpha 1,2$-fucosyltransferase, but was always found associated with Fut2 alleles coding for active enzymes that could compensate for the inability of Sec1 to synthesise $\mathrm{H}$ type 2 . The authors hypothesised that this $\operatorname{Sec} 1$ allele was probably associated with a mutation located in the regulatory region of Fut 2 which had compromised the Fut2 enzymes and, therefore, the synthesis of the virus' ligand. This result suggests that allelic variation in the $\alpha 1,2$-fucosyltransferase gene appears to have a significant role in resistance to RHDV. More recently, experimental challenge experiments indicated that at low virus titres, adult rabbits expressing low amounts of the HBGA ligands were less susceptible to the disease than animals expressing high amounts, although all animals were infected [117].

One striking characteristic of the pathogenesis is that of resistance of young rabbits less than 2 months of age to RHD [72]. Indeed, kittens less than 3 weeks old are fully resistant, but when infected at an age of 4 weeks or older the mortality rates increase to reach, at about 9 weeks old, the rates observed for adult individuals [10].
Thus, the mechanisms of resistance to RHDV have also been studied in light of the differences observed between adult and young rabbits. Interestingly, in young-resistant rabbits the attachment factor $\mathrm{H}$ type 2 has been shown to be weakly expressed on the epithelial cells of the upper respiratory and digestive tracts, where primary infection by the virus is believed to occur $[82,106]$, which could explain their resistance to infection. Nevertheless, the reasons behind this differential expression have not yet been disclosed and the picture seems to be far more complicated. Indeed, and despite compelling evidence that supports a role of carbohydrates in facilitating infection by RHDV in epithelial cells of the upper respiratory and digestive tracts, other attachment factors or receptors must be playing a role at the epithelial level since low expression of the carbohydrate receptor at the doors of entry confers only partial protection against infection [117]. In addition, hepatocytes, the main cellular target for viral replication, have been shown not to express HBGA [82] and, in young rabbits, infection is accompanied by hepatic lesions due to virus replication as in adult individuals, although they tend to be more severe in 4 week old than in 2 week old rabbits $[96,99,100,125,126]$. This indicates the existence of at least additional hepatic cellular receptor(s) and that the genetic basis for the resistance mechanisms goes beyond the attachment of the virus to host cells through histo-blood group antigens. Immune response related-genes, either of the innate or the adaptive responses, are obvious candidate genes to be involved in the resistance mechanisms to RHDV and should deserve attention in future studies.

Differences in the innate immune response between RHDV-infected adult and young rabbits have also been observed $[96,99,125-127]$. Heterophils seem to be the predominant type of leukocyte in the liver inflammatory infiltrates in adult rabbits and are in close proximity with damaged hepatocytes probably being involved in the clearance of the dead cells. At variance, in young rabbits, this infiltrate is composed mostly by lymphocytes associated with undamaged and possibly antigenpresenting hepatocytes [127] and which are likely to mount a more effective and specific immune response than heterophils. In addition, in young rabbits only a small fraction of hepatocytes supports viral replication indicating that structural and functional changes have to occur in the liver to support RHDV replication $[10,96,126]$.

Development of enzyme-linked immunosorbent assays (ELISA) for the diagnosis of RHD [29,35] allowed an early determination of the importance of humoral immunity in the course of the disease. Indeed, animals experiencing subacute forms of RHDV that survived infection and that were later resistant upon re-exposure 
to RHDV where shown to present high levels of seroconversion $[35,72,128,129]$. A correlation between cELISA titres and protection has been established which is important for determination of the applicability of vaccination and to assess the current status of the disease $[54,128,130,131]$. Recovering rabbits present IgM titres that quickly reach a maximum within 2 weeks and then sharply decrease. IgA titres are more prolonged in time, but they also face a decrease. In contrast, IgG slowly increase and are able to persist for months. With regards to IgA, this suggests a mucosal response [128]. Passive immunization (serotherapy) was also shown to be effective in stopping RHD in a rabbit farm hit by an outbreak [132], demonstrating the importance of humoral immunity in protection against RHD. In young rabbits, resistance has also been associated with the presence of maternal antibodies which are maintained during the period of life when they are considered RHD-resistant [128]. These are exclusively IgG acquired through the placenta in the last days of pregnancy and show a decline with age and body weight [19]. Additionally, if young rabbits are infected in their early life, they will become resistant when adult, suggesting that their immune system is capable of recognising the virus and producing an effective immune response that will confer long-term protection [133]. Therefore, humoral immunity clearly provides protection against RHDV when present $[28,103]$.

\section{Genetic diversity/RHDV evolution 7.1. Pathogenic RHDV}

The origin and evolution of RHDV are not well understood. Although first reported in China in Angora rabbits imported from Germany, it was not clear if rabbits were already infected with RHDV when they arrived in China, since the disease might have been previously observed in Germany [73], or if they became infected later in China. The idea of RHDV being of Chinese origin has been challenged by several studies [50,134-136]. Indeed, these studies have shown that the pathogenic form of RHDV originated before $1984[50,134,136]$ and that the Chinese strain isolated in 1984 had its origin in European isolates [135]. In light of these results, it seems that RHDV had its origins in Europe and that it had been circulating for some time, but that mortalities went unnoticed. Some hypotheses have been put forward regarding how RHDV originated. One of them, the transmission of the European brown hare syndrome virus to the European rabbit [137] has been discarded since EBHSV does not infect European rabbits. Other hypotheses propose that a virus from another species jumped to the rabbit where it became pathogenic [138], but the presently favoured hypothesis would be the change of a non-pathogenic virus closely related to RHDV and that rendered it pathogenic (see below).
Identifying novel features in the genome of RHDV might give some indications on the origin of the virus and its virulence. The first complete genome sequence of RHDV was obtained in 1991 by Meyers et al. [26]. The characterisation of the genetic diversity was initiated by sequencing and comparing partial sequences of a few European isolates [139-141]. The isolates were found to be highly similar and closely related.

Later, in an attempt to characterise the relation between EBHSV and RHDV, Wirblich et al. presented evidence that the $\mathrm{N}$ terminal portion of the capsid was highly conserved while the highest degree of variability was located in the C terminal half [39]. Indeed, while for the $\mathrm{N}$-terminus homology between caliciviruses is $\sim 80 \%$, no strict conservation was observed for the C-terminus. In RHDV, this highly variable portion seems to correspond to the $\mathrm{C}$ and $\mathrm{E}$ domains as defined by Neill [47], where the majority of the differences between calicivirus isolates have been detected and where the main antigenic determinants have been found to be located $[43,44,47,142-144]$. These domains were predicted to be located at the capsid surface [46] and therefore more variable as a result of the strong selective pressure due to exposure to the host immune system.

In 1997, the first phylogenetic analysis of RHDV isolates with different geographic locations and spanning the years from 1987 to 1995 was performed [137]. Inclusion of all the available information identified three major branches and supported the high degree of homology between samples, as previously reported, but also showed that RHDV strains clustered according to the year of isolation and not according to their geographic location. Le Gall et al. found the same pattern among French isolates, and further assigned the isolates into three chronologically established genogroups, G1, G2 and G3 [145]. Later, they observed that in France G1 and G2 had disappeared and three new genogroups had emerged: G4, having evolved from G3; G5, as a new independent group, and G6 (Figure 4) [14]. Interestingly, this genogroup G6 corresponded to the first antigenic variant of RHDV previously detected by Capucci et al. which they have designated as RHDVa [142]. This variant, although having the same level of pathogenicity as other RHDV isolates, presented a distinct antigenic profile and characteristic genetic differences [142]. Indeed, most of the amino acid variability found in RHDVa isolates was clustered in the 5 ' region of region $\mathrm{E}$ (spanning the amino acid positions 344-370), no reactivity was observed with the monoclonal antibody $1 \mathrm{H} 8$ that confers protection to experimentally-infected rabbits, but inoculation of vaccinated rabbits with RHDVa isolates caused no death $[142,146]$. RHDVa appears as a subtype of the RHDV wild-type (RHDVwt). These variants have been isolated in several countries and were detected as 


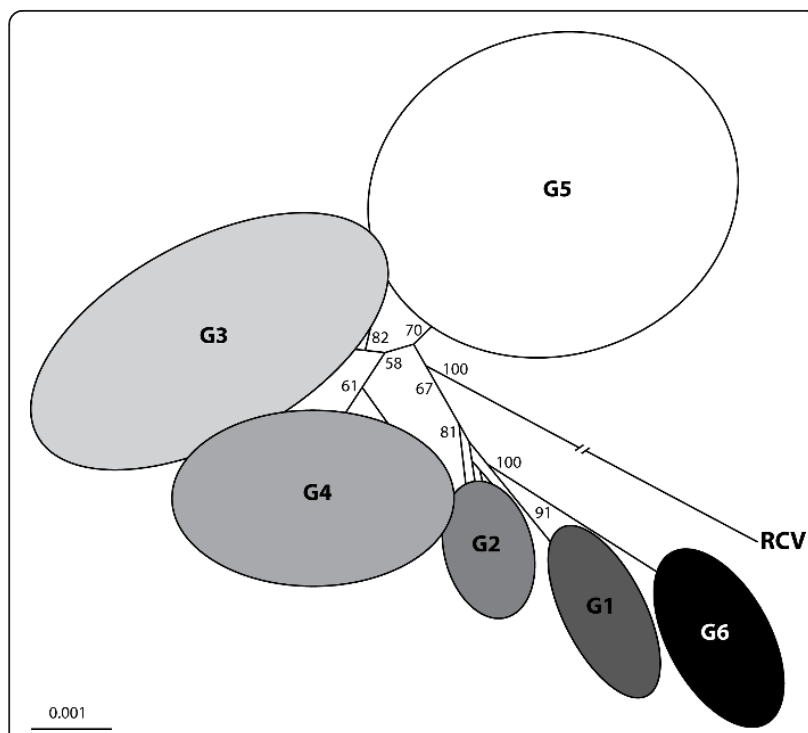

Figure 4 Phylogenetic relationships between the RHDV genogroups G1-G6 and the Italian non-pathogenic strain RCV. The tree was obtained using the neighbour-joining method and using nucleotide sequences from RHDV strains isolated worldwide. Bootstrap values greater than $50 \%$ are presented at the nodes. RCV was used as outgroup to root the tree. With kind permission from Springer Science + Business Media: Archives of Virology,

Phylogenetic analysis of rabbit haemorrhagic disease virus in France between 1993 and 2000, and the characterisation of RHDV antigenic variants, 148(1), 2003, 72, Le Gall-Recule G, Zwingelstein F, Laurent S, de Boisseson C, Portejoie Y, Rasschaert D, Figure 2 (the figure includes minor alterations).

early as 1985 in China, where they might have emerged $[13,136,146-150]$. In some areas, these variants seem to be replacing the original strains [148].

In the Iberian Peninsula, only G1 strains have been found, even among contemporary strains [91,134]. This differs with the general pattern of RHDV evolution observed in other European countries, but, overall, G1 strains seem to evolve following a temporal rather than a geographic pattern as observed in the other genogroups [91]. This temporal structure is common in RNA viruses and likely results from the strong selection imposed by adaptive immune recognition by the host [151]. This was confirmed for RHDV, where a few positively selected codons were detected located in the major antigenic determinants of the capsid [49,50,134]. Interestingly, all the positively selected codons were associated with potential N-glycosylation sites. Glycosylation is known to play a role in the infectious process in other non-enveloped viruses such as rotavirus and Hepatitis E virus [152-155]. Positive selection recorded at $\mathrm{N}$-glycosylation sites in the capsid protein of RHDV indicates that glycans might influence viral pathogenicity. This is further supported by the finding of nonpathogenic RHDV-like strains which do lack some of the positively selected N-glycosylation sites [49] although it is not known at present if the capsid protein from authentic virions is actually glycosylated.

Overall, with the exception of the RHDVa isolates, the evolution of RHDV is associated with a high degree of genetic homogeneity, with maximum nucleotide and amino acid differences of $10 \%$ and $6 \%$, respectively $[14,90,91,137,139-141,145,147,150,156-163]$, and mostly located in the regions $C$ and $E$. These differences are much lower than those observed for other caliciviruses (e.g. for Norovirus, amino acid differences can reach a maximum of $61.4 \%$ while for Sapovirus they can reach $55 \%)[164,165]$. This high homology may have resulted from the rapid spread of a new virus, expanding into a susceptible host population [139], but also from the fact that RHDV is a newly emerging pathogen whose evolution started recently, at variance from that of Norovirus and Sapovirus.

\subsection{Non-pathogenic rabbit calicivirus}

The emergence of RHDV from a pre-existing nonpathogenic rabbit calicivirus that has mutated and become pathogenic to rabbits has been hypothesised $[136,139,160,166-168]$. The detection of antibodies specific to RHDV in rabbit sera collected before the first RHDV outbreak, the identification of RHDV-seropositive rabbits where RHD was never recorded and the presence or persistence of viral RNA in populations where no overt signs of disease could be observed, provided compelling evidence for the pre-existence of a nonpathogenic RHVD-like virus in European rabbit populations [29,128,160,169-179]. This non-pathogenic virus would share antigenic properties with RHDV and circulated asymptomatically amongst rabbit populations before the first RHDV outbreak in China. Isolation of several non-pathogenic rabbit caliciviruses related to RHDV but with a tropism limited to the gut and no obvious pathogenicity further substantiated this hypothesis $[160,166,168,176,180,181]$ and showed that the nonpathogenic strains are still circulating. Protection to RHD had been shown to be conferred by some of these non-pathogenic strains which might provide an explanation for the low level of RHD incidence in some regions of Australia and Britain [166,168,169,171,173,179, 182-184]. More recently this hypothesis was confirmed experimentally when Strive et al. showed that the nonpathogenic Australian strain RCV-A1 is able to generate an antibody response that cross-reacts to RHDV and further protects animals from RHD, but not completely and not from infection [184]. Other strains, however, do not confer any kind of protection $[181,185]$.

Understanding the evolutionary history and the origin of RHDV will benefit from further studies of the nonpathogenic strains. The isolation of non-pathogenic 
strains has so far already revealed striking differences between these strains and the pathogenic RHDV strains, with the most important being, beside pathogenicity, tissue tropism and capsid variability $[160,166,168,176,180]$. Interestingly, MRCV, a new variant of the non-pathogenic rabbit calicivirus ( $\mathrm{RCV}$ )-like group that was recently characterised $[180,186]$, displayed a pathogenicity of approximately $30 \%$ which is significant and in contrast with reports from other non-pathogenic strains. The viral RNA of this strain was detected in the liver rather than in the intestine which seems to indicate that the ability of a strain to cross the epithelia barrier and reach other organs such as the liver is an important feature for the emergence of the pathogenic forms and should be further explored. However, these results should be considered with caution since experimental reproduction of the disease failed, with only 2 out of the 14 inoculated rabbits presenting very mild symptoms.

Despite the accumulation of data, no mutations have yet been attributed that would explain the switch from a non-pathogenic to a pathogenic form. Recombination within the RHDV genome is not uncommon $[187,188]$ and might have played a role in the origin of RHDV. Indeed, the recombination event reported by Forrester et al. [188] in the strain isolated in 1984 in China may suggest that recombination was a common mechanism at the time of emergence of the pathogenic forms. Nevertheless, not all pathogenic forms are direct descendants of this strain [135] and despite the relatively high frequency at which recombination occurs (4 out of 10), it does not seem to be widespread in all RHDV lineages [136]. This might be the result of an incomplete and non-systematic sampling or of the scarcity of complete genomic sequences.

Recently, novel phylogenetic analysis approaches were used to assess the emergence of RHDV $[50,134,136]$. Although the results could have brought an insight into the timing of the appearance of the non-pathogenic and the pathogenic forms of the virus, the studies led to incongruent results most likely as the result of the different capsid fragment lengths used in each study. This poses the question if the capsid is indeed the best gene for inferring RHDV history. While Kerr et al. could establish the Time to Most Recent Common Ancestor (TMRCA) between RHDV and the non-pathogenic forms of $<550$ years and of $<150$ years for the pathogenic forms [136], Kinnear and Linde set the existence of the ancestor of RHDV-RCV later in the 1930s and of the ancestor of the pathogenic RHDV strains between 1957-1976 [50]. Consistent with the findings of Kerr et al., Alda et al. set the TMRCA for all the RHDV to $\sim 1884$ [134]. Nevertheless, and considering these estimates, it is surprising that the disease had not been reported earlier than 1984 . This might suggest an alternative scenario for the virus emergence where the virus would have come from another species through a species jump, that would have acted as a reservoir and was not affected by RHDV [136]. This scenario, however, implies the existence of such a reservoir host in which the virus was able to replicate. Viral RNA has been recently detected and isolated in micromammals living in sympatry with European rabbit populations that could represent the unidentified reservoir [94], but viral replication within these species could not be confirmed. Since these species might be important for virus transmission and spread and perhaps represent the "unknown" reservoir for when the virus seems to be inactive, i.e. between outbreaks, this hypothesis should be further explored.

\section{Host-virus co-evolution}

The virus-host dynamics result in a co-evolutionary process between the host resistance mechanisms and the virus escape mechanisms with attenuation of the virus and/or increase in resistance of the host. Therefore, the study of the host-virus co-evolutionary processes requires the analysis of each element of this dynamical pair simultaneously. Regarding the host, and in order to identify signatures of selection due to infectious agents, the natural history of this species should be considered. The fossil record suggests that the European rabbit originated in the Iberian Peninsula during the medium Pleistocene [189-192] and two morphologically differentiated subspecies have been distinguished: $O$. cuniculus algirus and O. cuniculus cuniculus [193]. O. c. algirus inhabits the southwestern Iberian Peninsula, while O. $c$. cuniculus is present in the northeastern Iberian Peninsula. These two subspecies diverged $\sim 1.8$ Mya [reviewed in [194]] and then, by a post-glaciation expansion from the southwestern refugium to North and from the Northeastern to South or West, a contact zone was established. While the natural populations of $O$. $c$. algirus remained confined to the southwest of the Peninsula, the natural populations of O. c. cuniculus later expanded its range north towards France, likely after the last glacial peak [195], where they still remain present. The expansion of these populations with successive bottleneck events caused a significantly lower genetic diversity of the wild French O. c. cuniculus populations compared to the Iberian populations [195-201]. The European rabbit gene pool has been manipulated by man through a recent single domestication event of French origin, and therefore, all domestic rabbits belong to the subspecies O. c. cuniculus [reviewed in [201,202]]. Today, by man-mediated dispersal, the subspecies O. c. cuniculus can be found in Europe, Australia, New Zealand, North and South America, and North Africa. The gene pool of the European rabbit 
populations worldwide have been shaped differently by these events and this might have also interfered with the resistance mechanisms. Therefore, when studying the co-evolution between the European rabbits and RHDV, these events should be taken into account.

The introduction of myxoma virus in Australia was soon followed by an increase in genetic resistance in rabbits and the appearance of less virulent strains [203]. Recent field studies conducted in Australia suggest that RHDV also has become less effective in keeping wild rabbit numbers low and that in some populations rabbit numbers are returning to the pre-RHDV levels [204]. Laboratory challenges have confirmed this scenario when inoculation of rabbits from different Australian populations with the original introduced strain (Czech strain V351) failed to induce mortality or induced mortality rates lower than that which was expected [205]. In addition, in an Australian population, the frequency of host resistant phenotypes, i.e., phenotypes that confer a weak binding of the virus to the host HBGA that facilitate infection and thus provide protection to the host, has significantly increased [117]. A similar co-adaptation process seems to be occurring both in New Zealand [92] and in rabbit populations from Europe [117]. Indeed, Nyström et al. found that in a French wild rabbit population recovering from a major RHDV outbreak the frequency of resistant phenotypes increased among the survivors [117]. As with the Australian population, the resistant phenotypes are associated with weak viral binding. This indicates that the virus has contributed to select resistant hosts in accordance to the binding specificities of the circulating RHDV strains and gives further support for a role of the HBGA in the virus epidemiology and suggests that the virus is shaping the hosts' HBGA diversity.

The virus also seems to be evolving to overcome the host resistance mechanisms since significant mortalities are still observed in the field, at least in Australia. Evidence for this comes from the fact that in comparative trials in rabbits known to be resistant to infection with Czech 351, modern field strains appeared more virulent than the original released strain, suggesting they had evolved to keep pace with changes in rabbit resistance [205]. In addition, HBGA specificities of the strains that evolved in France from 1988 to 2009 progressively shifted, allowing preferential recognition of subgroups of animals that express distinct HBGA motifs, which suggests an adaptation to the host genetic diversity [117].

\section{Prevention, control and vaccination}

In animals presenting subclinical or no clinical signs, passively acquired immunity has been shown to act successfully in emergency situations [132]. Indeed, this therapy, which is achieved by inoculation with a hyperimmune antiserum, confers short-term protection, preventing death. Nevertheless, passive immunization is ineffective on animals presenting clinical signs. Thus, as yet, no cure is available for RHDV-dying rabbits. Prevention and control of the disease through biosecurity and immunoprophylactic measures such as vaccination are, therefore, of utmost importance. Due to the lack of a cell culture system for efficient virus propagation, commercially available vaccines against RHDV are produced from tissue suspensions of experimentally infected rabbits, followed by chemical inactivation of the virus $[132,177,206]$. However, and to obviate the risks inherent to the manufacturing and use of this kind of vaccines (the use of infectious particles, the need for a safe disposal of contaminant residues, social concerns on animal welfare) the RHDV capsid protein has been tested in various studies as a subunit vaccine against RHD. Several heterologous expression systems or recombinant animal viruses have been developed to produce recombinant versions of the VP60 protein. The VP60 recombinant protein has been produced in Escherichia coli [140]; insect cultured cells [59,101-104]; yeast [207,208]; plants [209-213]; insect larvae [214] and recombinant animal-derived viruses [215-219]. Most of these systems were shown to be immunogenic and to confer protection against lethal doses of RHDV by eliciting a humoral response indicating that they are good substitutes for the tissue vaccines. Features such as low cost, high yields and ease of scaling up are amongst the most important factors for their commercial viability.

Although commercially available vaccines have proven effective in rabbitries, in wild rabbit populations vaccination campaigns are economically and logistically impracticable and their effects are considered insignificant [220]. Indeed, administration to wild rabbits implies capturing and handling of rabbits which by being a stress factor might increase the mortality rates [221]. In addition, this would need to be performed systematically since induced-immunity lasts no longer than 1 year [222] and efficacy has been shown to be dependent on several physiological parameters of the individuals [223]. Therefore, alternative approaches are being explored to overcome these limitations such as the development of vaccines with the capacity for horizontal transmission to ensure appropriate immunization of a relevant portion of the population [219], vaccines that may be administered by the oral or nasal routes $[105,208,213,217,219$, $224,225]$ or the construction of bivalent vaccines $[216,226]$. Nevertheless, as yet, none of these vaccines has been registered or is commercially available.

Biosecurity measures for control and prevention of RHD, including surveillance, sanitation, disinfection and quarantine, are of high importance to limit propagation and to ensure prevention of the disease in particular in 
the rabbit industry. In countries where RHDV circulates in wild rabbits and where eradication is not achievable, these measures might prevent large-scale infection in rabbitries. Thus, a careful and correct management of the RHDV outbreaks is always dependent on the epidemiological situation of the regions where they occur. In addition, a continuous monitoring of the viral evolution in the field is fundamental for the quick detection of new genetic and antigenic variants which might be determinant for the application of the most appropriate measures.

\section{Therapeutic applications of RHDV}

More recently, RHDV VLP have been considered as a mean for cancer and pathogen immunotherapies [227-232]. The capsid protein of RHDV spontaneously assembles into VLP which are morphologically and antigenically indistinguishable from native virions, but devoid of the viral RNA [101]. By genetic engineering, RHDV VLP have been shown to efficiently incorporate antigens that might be presented to immune cells and to elicit an adequate cell-mediated and humoral immune response [228-232]. In addition, RHDV VLP have the advantage of being easily produced and at low cost, and, by deriving from a non-human virus, they are not susceptible to pre-existing neutralising antibodies [228], thus providing a reliable molecular tool for therapeutic applications.

RHDV has also been investigated for the study of virally-induced acute liver failure (ALF) in humans [233-239] as it fulfils several of the requirements to be a good animal model [233]. ALF is a condition characterised by severe liver injury, hepatic encephalopathy, coagulopathy and multiorgan failure, with viral infections (e.g. hepatitis A, B and E) and drug use (e.g. paracetamol overdose) amongst the commonest causes [240]. The hepatic lesions observed following infection by RHDV [99] resemble those caused by ALF in humans, but other physiologic, histological and biochemical alterations are also shared. Indeed, the hemodynamic changes, alterations in the intracranial pressure and histological alterations such as apoptosis observed in RHDV are common to ALF $[74,233,241,242]$. In addition, clinical symptoms such as prostration or convulsions observed on RHD are also observed in ALF [38]. RHDV has also been used for the study of therapeutic approaches for ALF [236,238,239].

\section{Conclusions}

Despite the lack of an appropriate cell culture system, some light has been shed on several aspects of RHDV and RHD. Nevertheless, the host-parasite interactions established between RHDV and the European rabbit are still unclear. Indeed, the role of some of the proteins encoded by RHDV is still unknown and the emergence of RHDV as a pathogenic form has not yet been resolved. In order to clarify these gaps, an effort should be made in obtaining full genomic sequences, including for non-pathogenic strains as these might contribute to understand the pathogenesis of RHDV. As for the host, and in particular as for key factors of susceptibility and resistance, the rabbit genome project should be considered and used for the study of candidate genes. By using temporal samples, i.e., samples of rabbits collected before and after RHDV outbreaks, one might determine those candidate genes. Further studies on immunity to RHDV and on the related non-pathogenic viruses are also warranted for a better understanding of the hostpathogen relationships. In addition, the study of the closely related EBHSV and its host, might contribute to the understanding of the interplay between lagoviruses and leporid species. The possibility that RHDV might be used as a model for the study of other calicivirus infections, in particular in view of its non-pathogenicity for humans, as well as for the development of anti-cancer and pathogen therapies transforms it into a valuable research molecular tool.

\section{List of abbreviations}

RHDV: rabbit haemorrhagic disease virus; RHD: rabbit haemorrhagic disease; EBHSV: European brown hare syndrome virus; EBHS: European brown hare syndrome; gRNA: genomic RNA; sgRNA: subgenomic RNA; VPg: virus genome-linked protein; ORF: open reading frame; RdRp: RNA-dependent RNA polymerase; DIC: disseminated intravascular coagulation; pi: post-infection; VLP: virus-like particles; HBGA: histo-blood group antigens; TURBS: termination upstream ribosomal binding site; RCV: rabbit calicivirus; TMRCA: Time to Most Recent Common Ancestor; ALF: acute liver failure.

\section{Acknowledgements}

The Portuguese Foundation for Science and Technology supported the post-doctoral fellowships of JA (SFRH/BPD/73512/2010) and PJE (SPRH/BPD/ 27021/2006). JLP was supported by a grant from the Région des Pays de la Loire (Calilago).

\section{Author details}

${ }^{1} \mathrm{ClBIO} / \mathrm{UP}$, Centro de Investigacao em Biodiversidade e Recursos Geneticos/ Universidade do Porto, Campus Agrario de Vairao, 4485-661 Vairao, Portugal. ${ }^{2}$ INSERM, U892, Université de Nantes, 44007 Nantes, France. ${ }^{3}$ CITS, Centro de Investigacao em Tecnologias de Saude, CESPU, Gandra, Portugal.

\section{Authors' contributions}

JA performed a study on the available literature on the subject, analysed the retrieved information and wrote the manuscript. WvdL, JLP and PJE revised the manuscript critically according to their own area of expertise. All authors read and approved the final manuscript.

\section{Competing interests}

The authors declare that they have no competing interests. 
Received: 20 July 2011 Accepted: 10 February 2012

Published: 10 February 2012

\section{References}

1. Liu SJ, Xue HP, Pu BQ, Qian NH: A new viral disease in rabbit. Anim Husb Vet Med 1984, 16:253-255.

2. Xu WY: Viral haemorrhagic disease of rabbits in the People's Republic of China: epidemiology and virus characterisation. Rev Sci Tech 1991, 10:393-408.

3. Park NY, Chong CY, Kim JH, Cho SM, Cha YH, Jung BT, Kim DS, Yoon JB: An outbreak of viral haemorrhagic pneumonia (tentative name) of rabbits in Korea. J Korean Vet Med Assoc 1987, 23:603-610.

4. Cancellotti FM, Renzi M: Epidemiology and current situation of viral haemorrhagic disease of rabbits and the European brown hare syndrome in Italy. Rev Sci Tech 1991, 10:409-422.

5. Delibes-Mateos M, Delibes M, Ferreras P, Villafuerte R: Key role of European rabbits in the conservation of the Western Mediterranean basin hotspot. Conserv Biol 2008, 22:1106-1117

6. Argüello JL, Llanos A, Pérez Ll: Enfermedad hemorrágica del conejo en España. Med Vet 1988, 5:645-650, (in Spanish).

7. Anonymous: Doença hemorrágica a vírus do Coelho em Portugal. Rev Port Ciênc Vet 1989, 84:57-58, (in Portuguese).

8. Villafuerte R, Calvete C, Blanco JC, Lucientes J: Incidence of viral hemorrhagic disease in wild rabbit populations in Spain. Mammalia 1995, 59:651-660.

9. Delibes-Mateos M, Ferreras P, Villafuerte R: Rabbit populations and game management: the situation after 15 years of rabbit haemorrhagic disease in central southern Spain. Biodivers Conserv 2008, 17:559-574.

10. Morisse JP, Le Gall G, Boilletot E: Hepatitis of viral origin in Leporidae: introduction and aetiological hypotheses. Rev Sci Tech 1991, 10:283-295.

11. Gregg DA, House C, Meyer R, Berninger M: Viral haemorrhagic disease of rabbits in Mexico: epidemiology and viral characterization. Rev Sci Tech 1991, 10:435-451.

12. Rabbit calicivirus infection confirmed in lowa rabbitry. J Am Vet Med Assoc 2000, 216:1537.

13. Farnos $\mathrm{O}$, Rodriguez D, Valdes $\mathrm{O}$, Chiong M, Parra F, Toledo JR, Fernandez E, Lleonart R, Suarez M: Molecular and antigenic characterization of rabbit hemorrhagic disease virus isolated in Cuba indicates a distinct antigenic subtype. Arch Virol 2007, 152:1215-1221.

14. Le Gall-Recule G, Zwingelstein F, Laurent S, de Boisseson C, Portejoie Y, Rasschaert D: Phylogenetic analysis of rabbit haemorrhagic disease virus in France between 1993 and 2000, and the characterisation of RHDV antigenic variants. Arch Virol 2003, 148:65-81.

15. Delibes-Mateos M, Redpath SM, Angulo E, Ferreras P, Villafuerte R: Rabbits as a keystone species in southern Europe. Biol Conserv 2007, 137:149-156.

16. Mitro S, Krauss H: Rabbit hemorrhagic disease: a review with special reference to its epizootiology. Eur J Epidemiol 1993, 9:70-78.

17. Gibb JA, Williams JM: The rabbit in New Zealand. In The European rabbit: the history and biology of a successful colonizer. Edited by: Corbet GB, Flux JEC, Rogers PM, Arthur CP, Soriguer RC, Myers K, Parer I, Wood D, Cooke BD, Gibb JA Williams JM, Fenner F, Ris J, Thompson HV, King CM. Oxford: Oxford University Press; 1994:158-200.

18. Fenner F: Deliberate introduction of the European rabbit, Oryctolagus cuniculus, into Australia. Rev Sci Tech 2010, 29:103-111.

19. Cooke BD: Rabbit haemorrhagic disease: field epidemiology and the management of wild rabbit populations. Rev Sci Tech 2002, 21:347-358.

20. Cooke BD, Fenner F: Rabbit haemorrhagic disease and the biological control of wild rabbits, Oryctolagus cuniculus, in Australia and New Zealand. Wildl Res 2002, 29:689-706

21. Mutze $G$, Cooke B, Alexander P: The initial impact of rabbit hemorrhagic disease on European rabbit populations in South Australia. J Wildl Dis 1998, 34:221-227.

22. Thompson J, Clark G: Rabbit calicivirus disease now established in New Zealand. Surveillance 1997, 24:5-6.

23. O'Keefe JS, Tempero J, Atkinson PH, Pacciarini L, Fallacara F, Horner GW, Motha J: Typing of rabbit haemorrhagic disease virus from New Zealand wild rabbits. N Z Vet J 1998, 46:42-43.

24. An S-H, Kim B-H, Lee JB, Song JU, Park BK, Kwon YB, Jung JS, Lee YS: Studies on Picornavirus hemorrhagic fever (tentative name) in rabbit. 1. Physico-chemical properties of the casuative virus. Res Rep Rural Dev Adm 1988, 30:55-61.
25. Gregg DA, House C: Necrotic hepatitis of rabbits in Mexico: a parvovirus. Vet Rec 1989, 125:603-604.

26. Meyers G, Wirblich C, Thiel HJ: Rabbit hemorrhagic disease virusmolecular cloning and nucleotide sequencing of a calicivirus genome. Virology 1991, 184:664-676.

27. Ohlinger VF, Haas B, Meyers G, Weiland F, Thiel HJ: Identification and characterization of the virus causing rabbit hemorrhagic disease. J Virol 1990, 64:3331-3336.

28. Parra F, Prieto $M$ : Purification and characterization of a calicivirus as the causative agent of a lethal hemorrhagic disease in rabbits. J Virol 1990, 64:4013-4015.

29. Rodak L, Smid B, Valicek L, Vesely T, Stepanek J, Hampl J, Jurak E: Enzymelinked immunosorbent assay of antibodies to rabbit haemorrhagic disease virus and determination of its major structural proteins. J Gen Virol 1990, 71:1075-1080.

30. Moussa A, Chasey D, Lavazza A, Capucci L, Smid B, Meyers G, Rossi C, Thiel HJ, Vlasak R, Ronsholt L, Nowotny N, McCullough K, Gavier-Widen D: Haemorrhagic disease of lagomorphs: evidence for a calicivirus. Vet Microbiol 1992, 33:375-381.

31. Oliver SL, Asobayire E, Dastjerdi AM, Bridger JC: Genomic characterization of the unclassified bovine enteric virus Newbury agent-1 (Newbury1) endorses a new genus in the family Caliciviridae. Virology 2006, 350:240-250.

32. Farkas $T$, Sestak $K$, Wei $C$, Jiang $X$ : Characterization of a rhesus monkey calicivirus representing a new genus of Caliciviridae. J Virol 2008, 82:5408-5416.

33. L'Homme Y, Sansregret R, Plante-Fortier E, Lamontagne AM, Ouardani M, Lacroix G, Simard C: Genomic characterization of swine caliciviruses representing a new genus of Caliciviridae. Virus Genes 2009, 39:66-75.

34. Gavier-Widen D, Morner T: Descriptive epizootiological study of European brown hare syndrome in Sweden. J Wildl Dis 1993, 29:15-20.

35. Capucci L, Scicluna MT, Lavazza A: Diagnosis of viral haemorrhagic disease of rabbits and the European brown hare syndrome. Rev Sci Tech 1991, 10:347-370.

36. Chasey D, Lucas M, Westcott D, Williams M: European brown hare syndrome in the U.K.; a calicivirus related to but distinct from that of viral haemorrhagic disease in rabbits. Arch Virol 1992, 124:363-370.

37. Fuchs $\mathrm{A}$, Weissenbock $\mathrm{H}$ : Comparative histopathological study of rabbit haemorrhagic disease (RHD) and European brown hare syndrome (EBHS). J Comp Pathol 1992, 107:103-113.

38. Marcato PS, Benazzi C, Vecchi G, Galeotti M, Della Salda L, Sarli G, Lucidi P. Clinical and pathological features of viral haemorrhagic disease of rabbits and the European brown hare syndrome. Rev Sci Tech 1991 10:371-392.

39. Wirblich C, Meyers G, Ohlinger VF, Capucci L, Eskens U, Haas B, Thiel HJ: European brown hare syndrome virus: relationship to rabbit hemorrhagic disease virus and other caliciviruses. J Virol 1994, 68:5164-5173.

40. Lavazza A, Scicluna MT, Capucci L: Susceptibility of hares and rabbits to the European brown hare syndrome virus (EBHSV) and rabbit haemorrhagic disease virus (RHDV) under experimental conditions. Zentralb/ Veterinarmed B 1996, 43:401-410.

41. Thouvenin E, Laurent S, Madelaine MF, Rasschaert D, Vautherot JF, Hewat EA: Bivalent binding of a neutralising antibody to a calicivirus involves the torsional flexibility of the antibody hinge. J Mol Biol 1997, 270:238-246.

42. Valicek L, Smid B, Rodak L, Kudrna J: Electron and immunoelectron microscopy of rabbit haemorrhagic disease virus (RHDV). Arch Virol 1990, 112:271-275.

43. Barcena J, Verdaguer N, Roca R, Morales M, Angulo I, Risco C, Carrascosa JL, Torres JM, Caston JR: The coat protein of Rabbit hemorrhagic disease virus contains a molecular switch at the $\mathrm{N}$-terminal region facing the inner surface of the capsid. Virology 2004, 322:118-134.

44. Capucci L, Frigoli G, Ronshold L, Lavazza A, Brocchi E, Rossi C: Antigenicity of the rabbit hemorrhagic disease virus studied by its reactivity with monoclonal antibodies. Virus Res 1995, 37:221-238.

45. Hu Z, Tian X, Zhai Y, Xu W, Zheng D, Sun F: Cryo-electron microscopy reconstructions of two types of wild rabbit hemorrhagic disease viruses characterized the structural features of Lagovirus. Protein Cell 2010, 1:48-58. 
46. Prasad BV, Rothnagel R, Jiang X, Estes MK: Three-dimensional structure of baculovirus-expressed Norwalk virus capsids. J Virol 1994, 68:5117-5125.

47. Neill JD: Nucleotide sequence of the capsid protein gene of two serotypes of San Miguel sea lion virus: identification of conserved and non-conserved amino acid sequences among calicivirus capsid proteins. Virus Res 1992, 24:211-222.

48. Martinez-Torrecuadrada JL, Cortes E, Vela C, Langeveld JP, Meloen RH, Dalsgaard K, Hamilton WD, Casal J: Antigenic structure of the capsid protein of rabbit haemorrhagic disease virus. J Gen Virol 1998 79:1901-1909.

49. Esteves PJ, Abrantes J, Carneiro M, Muller A, Thompson G, van der Loo W: Detection of positive selection in the major capsid protein VP60 of the rabbit haemorrhagic disease virus (RHDV). Virus Res 2008, 137:253-256.

50. Kinnear $M$, Linde CC: Capsid gene divergence in rabbit hemorrhagic disease virus. J Gen Virol 2010, 91:174-181

51. Bu W, Mamedova A, Tan M, Xia M, Jiang X, Hegde RS: Structural basis for the receptor binding specificity of Norwalk virus. J Virol 2008, 82:5340-5347.

52. Cao S, Lou Z, Tan M, Chen Y, Liu Y, Zhang Z, Zhang XC, Jiang X, Li X, Rao Z: Structural basis for the recognition of blood group trisaccharides by norovirus. J Virol 2007, 81:5949-5957.

53. Choi JM, Hutson AM, Estes MK, Prasad BV: Atomic resolution structural characterization of recognition of histo-blood group antigens by Norwalk virus. Proc Natl Acad Sci USA 2008, 105:9175-9180

54. Lavazza A, Capucci L: How Many Caliciviruses are there in Rabbits? A Review on RHDV and Correlated Viruses Lagomorph Biology.Edited by: Alves PC, Ferrand N, Hackländer K. Springer Berlin Heidelberg; 2008:263-278.

55. Granzow H, Weiland F, Strebelow HG, Liu CM, Schirrmeier H: Rabbit hemorrhagic disease virus (RHDV): ultrastructure and biochemical studies of typical and core-like particles present in liver homogenates. Virus Res 1996, 41:163-172.

56. Alexandrov M, Peshev R, Bozhkov S, Yanchev I, Doumanova L: Electronand immunoelectron-microscopic investigation on the rabbit haemorrhagic disease virus. Comp Immunol Microbiol Infect Dis 1993 16:21-27.

57. Meyers G, Wirblich C, Thiel HJ, Thumfart JO: Rabbit hemorrhagic disease virus: genome organization and polyprotein processing of a calicivirus studied after transient expression of cDNA constructs. Virology 2000, 276:349-363.

58. Miller WA, Koev G: Synthesis of subgenomic RNAs by positive-strand RNA viruses. Virology 2000, 273:1-8.

59. Sibilia M, Boniotti MB, Angoscini P, Capucci L, Rossi C: Two independent pathways of expression lead to self-assembly of the rabbit hemorrhagic disease virus capsid protein. J Virol 1995, 69:5812-5815.

60. Boga JA, Marin MS, Casais R, Prieto M, Parra F: In vitro translation of a subgenomic mRNA from purified virions of the Spanish field isolate AST/89 of rabbit hemorrhagic disease virus (RHDV). Virus Res 1992, 26:33-40.

61. Neill JD, Reardon IM, Heinrikson RL: Nucleotide sequence and expression of the capsid protein gene of feline calicivirus. J Virol 1991, 65:5440-5447.

62. Machin A, Martin Alonso JM, Parra F: Identification of the amino acid residue involved in rabbit hemorrhagic disease virus VPg uridylylation. $J$ Biol Chem 2001, 276:27787-27792

63. Boniotti B, Wirblich C, Sibilia M, Meyers G, Thiel HJ, Rossi C: Identification and characterization of a $3 \mathrm{C}$-like protease from rabbit hemorrhagic disease virus, a calicivirus. J Virol 1994, 68:6487-6495.

64. Konig M, Thiel HJ, Meyers G: Detection of viral proteins after infection of cultured hepatocytes with rabbit hemorrhagic disease virus. J Virol 1998, 72:4492-4497.

65. Wirblich C, Thiel HJ, Meyers G: Genetic map of the calicivirus rabbit hemorrhagic disease virus as deduced from in vitro translation studies. $J$ Virol 1996, 70:7974-7983.

66. López Vázquez A, Martin Alonso JM, Casais R, Boga JA, Parra F: Expression of enzymatically active rabbit hemorrhagic disease virus RNA-dependent RNA polymerase in Escherichia coli. J Virol 1998, 72:2999-3004.

67. Marin MS, Casais R, Alonso JM, Parra F: ATP binding and ATPase activities associated with recombinant rabbit hemorrhagic disease virus $2 \mathrm{C}$-like polypeptide. J Virol 2000, 74:10846-10851

68. Machin A, Martin Alonso JM, Dalton KP, Parra F: Functional differences between precursor and mature forms of the RNA-dependent RNA polymerase from rabbit hemorrhagic disease virus. J Gen Virol 2009, 90:2114-2118.

69. Goodfellow I, Chaudhry Y, Gioldasi I, Gerondopoulos A, Natoni A, Labrie L, Laliberte JF, Roberts L: Calicivirus translation initiation requires an interaction between VPg and elF 4 E. EMBO Rep 2005, 6:968-972.

70. Liu G, Ni Z, Yun T, Yu B, Chen L, Zhao W, Hua J, Chen J: A DNA-launched reverse genetics system for rabbit hemorrhagic disease virus reveals that the VP2 protein is not essential for virus infectivity. J Gen Virol 2008, 89:3080-3085

71. Chen L, Liu G, Ni Z, Yu B, Yun T, Song Y, Hua J, Li S, Chen J: Minor structural protein VP2 in rabbit hemorrhagic disease virus downregulates the expression of the viral capsid protein VP60. J Gen Virol 2009, 90:2952-2955

72. Xu ZJ, Chen WX: Viral haemorrhagic disease in rabbits: a review. Vet Res Commun 1989, 13:205-212

73. Patton NM: Viral hemorrhagic disease. A major new disease problem of rabbits. Rabbit Res 1989, 12:64-67.

74. Alonso C, Oviedo JM, Martin-Alonso JM, Diaz E, Boga JA, Parra F: Programmed cell death in the pathogenesis of rabbit hemorrhagic disease. Arch Virol 1998, 143:321-332.

75. Park JH, Lee YS, Itakura C: Pathogenesis of acute necrotic hepatitis in rabbit hemorrhagic disease. Lab Anim Sci 1995, 45:445-449.

76. Ueda K, Park JH, Ochiai K, Itakura C: Disseminated intravascular coagulation (DIC) in rabbit haemorrhagic disease. Jpn J Vet Res 1992, 40:133-141.

77. Marques RM, Costa ESA, Aguas AP, Teixeira L, Ferreira PG: Early acute depletion of lymphocytes in calicivirus-infected adult rabbits. Vet Res Commun 2010, 34:659-668.

78. Asgari S, Hardy JR, Sinclair RG, Cooke BD: Field evidence for mechanical transmission of rabbit haemorrhagic disease virus (RHDV) by flies (Diptera:Calliphoridae) among wild rabbits in Australia. Virus Res 1998, 54:123-132.

79. Ohlinger VF, Haas B, Thiel HJ: Rabbit hemorrhagic disease (RHD): characterization of the causative calicivirus. Vet Res 1993, 24:103-116.

80. Chasey D: Possible origin of rabbit haemorrhagic disease in the United Kingdom. Vet Rec 1994, 135:496-499.

81. Frolich K, Klima F, Dedek J: Antibodies against rabbit hemorrhagic disease virus in free-ranging red foxes from Germany. J Wildl Dis 1998, 34:436-442.

82. Ruvoen-Clouet N, Ganiere JP, Andre-Fontaine G, Blanchard D, Le Pendu J: Binding of rabbit hemorrhagic disease virus to antigens of the $A B H$ histo-blood group family. J Virol 2000, 74:11950-11954

83. McColl KA, Morrissy CJ, Collins BJ, Westbury HA: Persistence of rabbit haemorrhagic disease virus in decomposing rabbit carcases. Aust Vet $J$ 2002, 80:298-299.

84. Henning J, Meers J, Davies PR, Morris RS: Survival of rabbit haemorrhagic disease virus (RHDV) in the environment. Epidemiol Infect 2005, 133:719-730.

85. Mutze G, Bird P, Kovaliski J, Peacock D, Jennings S, Cooke B: Emerging epidemiological patterns in rabbit haemorrhagic disease, its interaction with myxomatosis, and their effects on rabbit populations in South Australia. Wildl Res 2002, 29:577-590.

86. Mutze G, Bird P, Cooke B, Henzell R: Geographic and Seasonal Variation in the Impact of Rabbit Haemorrhagic Disease on European Rabbits, Oryctolagus cuniculus, and Rabbit Damage in Australia. Lagomorph Biology Springer Berlin Heidelberg; 2008, 279-293.

87. Calvete C: Modeling the effect of population dynamics on the impact of rabbit hemorrhagic disease. Conserv Biol 2006, 20:1232-1241.

88. Fouchet D, Le Pendu J, Guitton JS, Guiserix M, Marchandeau S, Pontier D: Evolution of microparasites in spatially and genetically structured host populations: the example of RHDV infecting rabbits. J Theor Biol 2009, 257:212-227

89. Van Regenmortel $\mathrm{MH}$, International, Fauquet CM: Virus Taxonomy: Classification and Nomenclature of Viruses: Seventh Report of the International Committee on Taxonomy of Viruses. Academic Press; 2000

90. Gould AR, Kattenbelt JA, Lenghaus C, Morrissy C, Chamberlain T, Collins BJ, Westbury HA: The complete nucleotide sequence of rabbit haemorrhagic disease virus (Czech strain V351): use of the polymerase chain reaction to detect replication in Australian vertebrates and analysis of viral population sequence variation. Virus Res 1997, 47:7-17. 
91. Muller A, Freitas J, Silva E, Le Gall-Recule G, Zwingelstein F, Abrantes J, Esteves PJ, Alves PC, van der Loo W, Kolodziejek J, Nowotny N, Thompson G: Evolution of rabbit haemorrhagic disease virus (RHDV) in the European rabbit (Oryctolagus cuniculus) from the Iberian Peninsula. Vet Microbiol 2009, 135:368-373.

92. Parkes JP, Glentworth B, Sullivan G: Changes in immunity to rabbit haemorrhagic disease virus, and in abundance and rates of increase of wild rabbits in Mackenzie Basin, New Zealand. Wildl Res 2008, 35:775-779.

93. Leighton FA, Artois M, Capucci L, Gavier-Widen D, Morisse JP: Antibody response to rabbit viral hemorrhagic disease virus in red foxes (Vulpes vulpes) consuming livers of infected rabbits (Oryctolagus cuniculus). J Wildl Dis 1995, 31:541-544

94. Merchan T, Rocha G, Alda F, Silva E, Thompson G, de Trucios SH, Pages A: Detection of rabbit haemorrhagic disease virus (RHDV) in nonspecific vertebrate hosts sympatric to the European wild rabbit (Oryctolagus cuniculus). Infect Genet Evol 2011, 11:1469-1474.

95. Jung JY, Lee BJ, Tai JH, Park JH, Lee YS: Apoptosis in rabbit haemorrhagic disease. J Comp Pathol 2000, 123:135-140.

96. Prieto JM, Fernandez F, Alvarez V, Espi A, Garcia Marin JF, Alvarez M, Martin JM, Parra F: Immunohistochemical localisation of rabbit haemorrhagic disease virus VP-60 antigen in early infection of young and adult rabbits. Res Vet Sci 2000, 68:181-187.

97. Gelmetti D, Grieco V, Rossi C, Capucci L, Lavazza A: Detection of rabbit haemorrhagic disease virus (RHDV) by in situ hybridisation with a digoxigenin labelled RNA probe. J Virol Methods 1998, 72:219-226.

98. Kimura T, Mitsui I, Okada Y, Furuya T, Ochiai K, Umemura T, Itakura C: Distribution of rabbit haemorrhagic disease virus RNA in experimentally infected rabbits. J Comp Pathol 2001, 124:134-141.

99. Mikami O, Park JH, Kimura T, Ochiai K, Itakura C: Hepatic lesions in young rabbits experimentally infected with rabbit haemorrhagic disease virus. Res Vet Sci 1999, 66:237-242.

100. Shien $J H$, Shieh HK, Lee LH: Experimental infections of rabbits with rabbit haemorrhagic disease virus monitored by polymerase chain reaction. Res Vet Sci 2000, 68:255-259.

101. Nagesha HS, Wang LF, Hyatt AD, Morrissy CJ, Lenghaus C, Westbury HA: Self-assembly, antigenicity, and immunogenicity of the rabbit haemorrhagic disease virus (Czechoslovakian strain V-351) capsid protein expressed in baculovirus. Arch Virol 1995, 140:1095-1108.

102. Gromadzka B, Szewczyk B, Konopa G, Fitzner A, Kesy A: Recombinant VP60 in the form of virion-like particles as a potential vaccine against rabbit hemorrhagic disease virus. Acta biochimica Polonica 2006, 53:371-376.

103. Laurent S, Vautherot JF, Madelaine MF, Le Gall G, Rasschaert D: Recombinant rabbit hemorrhagic disease virus capsid protein expressed in baculovirus self-assembles into viruslike particles and induces protection. J Virol 1994, 68:6794-6798.

104. Marin MS, Martin Alonso JM, Perez Ordoyo Garcia LI, Boga JA, ArguelloVillares JL, Casais R, Venugopal K, Jiang W, Gould EA, Parra F: Immunogenic properties of rabbit haemorrhagic disease virus structural protein VP60 expressed by a recombinant baculovirus: an efficient vaccine. Virus Res 1995, 39:119-128.

105. Plana-Duran J, Bastons M, Rodriguez MJ, Climent I, Cortes E, Vela C, Casal I: Oral immunization of rabbits with VP60 particles confers protection against rabbit hemorrhagic disease. Arch Virol 1996, 141:1423-1436.

106. Ruvoen-Clouet N, Blanchard D, Andre-Fontaine G, Ganiere JP: Partial characterization of the human erythrocyte receptor for rabbit haemorrhagic disease virus. Res Virol 1995, 146:33-41.

107. Farkas T, Cross RW, Hargitt E, Lerche NW, Morrow AL, Sestak K: Genetic diversity and histo-blood group antigen interactions of rhesus enteric caliciviruses. J Virol 2010, 84:8617-8625.

108. Hutson AM, Atmar RL, Graham DY, Estes MK: Norwalk virus infection and disease is associated with ABO histo-blood group type. J Infect Dis 2002 185:1335-1337.

109. Hutson AM, Atmar RL, Marcus DM, Estes MK: Norwalk virus-like particle hemagglutination by binding to $\mathrm{h}$ histo-blood group antigens. J Virol 2003, 77:405-415.

110. Lindesmith L, Moe C, Marionneau S, Ruvoen N, Jiang X, Lindblad L, Stewart P, LePendu J, Baric R: Human susceptibility and resistance to Norwalk virus infection. Nat Med 2003, 9:548-553.

111. Marionneau S, Ruvoen N, Le Moullac-Vaidye B, Clement M, CailleauThomas A, Ruiz-Palacois G, Huang P, Jiang X, Le Pendu J: Norwalk virus binds to histo-blood group antigens present on gastroduodenal epithelial cells of secretor individuals. Gastroenterology 2002, 122:1967-1977.

112. Rydell GE, Nilsson J, Rodriguez-Diaz J, Ruvoen-Clouet N, Svensson L, Le Pendu J, Larson G: Human noroviruses recognize sialyl Lewis $\mathrm{x}$ neoglycoprotein. Glycobiology 2009, 19:309-320.

113. Stuart AD, Brown TD: Alpha2,6-linked sialic acid acts as a receptor for Feline calicivirus. J Gen Virol 2007, 88:177-186.

114. Tamura M, Natori K, Kobayashi M, Miyamura T, Takeda N: Genogroup II noroviruses efficiently bind to heparan sulfate proteoglycan associated with the cellular membrane. J Virol 2004, 78:3817-3826.

115. Taube S, Perry JW, Yetming K, Patel SP, Auble H, Shu L, Nawar HF, Lee CH, Connell TD, Shayman JA, Wobus CE: Ganglioside-linked terminal sialic acid moieties on murine macrophages function as attachment receptors for murine noroviruses. J Virol 2009, 83:4092-4101.

116. Marionneau S, Cailleau-Thomas A, Rocher J, Le Moullac-Vaidye B, Ruvoen N, Clement $\mathrm{M}$, Le Pendu J: $\mathrm{ABH}$ and Lewis histo-blood group antigens, a model for the meaning of oligosaccharide diversity in the face of a changing world. Biochimie 2001, 83:565-573.

117. Nyström K, Le Gall-Reculé G, Grassi P, Abrantes J, Ruvoën-Clouet N, Le Moullac-Vaidye B, Lopes AM, Esteves PJ, Strive T, Marchandeau S, Dell A, Haslam SM, Le Pendu J: Histo-blood group antigens act as attachment factors of rabbit hemorrhagic disease virus infection in a virus straindependent manner. PLoS Pathog 2011, 7:e1002188.

118. Rademacher C, Krishna NR, Palcic M, Parra F, Peters T: NMR experiments reveal the molecular basis of receptor recognition by a calicivirus. J Am Chem Soc 2008, 130:3669-3675.

119. Abrantes J, Posada D, Guillon P, Esteves PJ, Le Pendu J: Widespread gene conversion of alpha-2-fucosyltransferase genes in mammals. J Mol Evol 2009, 69:22-31.

120. Daughenbaugh KF, Wobus CE, Hardy ME: VPg of murine norovirus binds translation initiation factors in infected cells. Virol J 2006, 3:33.

121. Rohayem J, Bergmann M, Gebhardt J, Gould E, Tucker P, Mattevi A, Unge T, Hilgenfeld R, Neyts J: Antiviral strategies to control calicivirus infections. Antiviral Res 2010, 87:162-178.

122. Meyers G: Translation of the minor capsid protein of a calicivirus is initiated by a novel termination-dependent reinitiation mechanism. $J$ Biol Chem 2003, 278:34051-34060.

123. Meyers $\mathrm{G}$ : Characterization of the sequence element directing translation reinitiation in RNA of the calicivirus rabbit hemorrhagic disease virus. $J$ Virol 2007, 81:9623-9632.

124. Guillon P, Ruvoen-Clouet N, Le Moullac-Vaidye B, Marchandeau S, Le Pendu J: Association between expression of the $\mathrm{H}$ histo-blood group antigen, alpha1,2fucosyltransferases polymorphism of wild rabbits, and sensitivity to rabbit hemorrhagic disease virus. Glycobiology 2009, 19:21-28.

125. Ferreira PG, Costa-e-Silva A, Aguas AP: Liver disease in young rabbits infected by calicivirus through nasal and oral routes. Res Vet Sci 2006, 81:362-365.

126. Ferreira PG, Costa-e-Silva A, Monteiro E, Oliveira MJ, Aguas AP: Transient decrease in blood heterophils and sustained liver damage caused by calicivirus infection of young rabbits that are naturally resistant to rabbit haemorrhagic disease. Res Vet Sci 2004, 76:83-94.

127. Ferreira PG, Costa ESA, Oliveira MJ, Monteiro E, Aguas AP: Leukocytehepatocyte interaction in calicivirus infection: differences between rabbits that are resistant or susceptible to rabbit haemorrhagic disease (RHD). Vet Immunol Immunopathol 2005, 103:217-221.

128. Cooke BD, Robinson AJ, Merchant JC, Nardin A, Capucci L: Use of ELISAs in field studies of rabbit haemorrhagic disease (RHD) in Australia. Epidemiol Infect 2000, 124:563-576.

129. Marchandeau S, Chaval Y, Le Goff E: Prolonged decline in the abundance of wild European rabbits Oryctolagus cuniculus and high immunity level over three years following the arrival of rabbit haemorrhagic disease. Wildlife Biol 2000, 6:141-147.

130. McPhee SR, Butler KL, Kovaliski J, Mutze G, Capucci L, Cooke BD: Antibody status and survival of Australian wild rabbits challenged with rabbit haemorrhagic disease virus. Wildl Res 2009, 36:447-456.

131. Zheng T, Parkes JP: Rabbit haemorrhagic disease: advantages of cELISA in assessing immunity in wild rabbits (Oryctolagus cuniculus). Vet Microbiol 2011, 153:387-392.

132. Huang HB: Vaccination against and immune response to viral haemorrhagic disease of rabbits: a review of research in the People's Republic of China. Rev Sci Tech 1991, 10:481-498. 
133. Ferreira PG, Dinis M, Costa ESA, Aguas AP: Adult rabbits acquire resistance to lethal calicivirus infection by adoptive transfer of sera from infected young rabbits. Vet Immunol Immunopathol 2008, 121:364-369.

134. Alda F, Gaitero T, Suarez M, Merchan T, Rocha G, Doadrio I: Evolutionary history and molecular epidemiology of rabbit haemorrhagic disease virus in the Iberian Peninsula and Western Europe. BMC Evol Biol 2010, 10:347.

135. Forrester NL, Trout RC, Turner SL, Kelly D, Boag B, Moss S, Gould EA: Unravelling the paradox of rabbit haemorrhagic disease virus emergence, using phylogenetic analysis; possible implications for rabbit conservation strategies. Biol Conserv 2006, 131:296-306.

136. Kerr PJ, Kitchen A, Holmes EC: Origin and phylodynamics of rabbit hemorrhagic disease virus. J Virol 2009, 83:12129-12138.

137. Nowotny N, Bascunana CR, Ballagi-Pordany A, Gavier-Widen D, Uhlen M, Belak S: Phylogenetic analysis of rabbit haemorrhagic disease and European brown hare syndrome viruses by comparison of sequences from the capsid protein gene. Arch Virol 1997, 142:657-673.

138. Fenner F, Fantini B: Biological control of vertebrate pests: the history of myxomatosis, an experiment in evolution. Wallingford: CABI Publishing; 1999.

139. Milton ID, Vlasak R, Nowotny N, Rodak L, Carter MJ: Genomic 3' terminal sequence comparison of three isolates of rabbit haemorrhagic disease virus. FEMS Microbiol Lett 1992, 72:37-42.

140. Boga JA, Casais R, Marin MS, Martin-Alonso JM, Carmenes RS, Prieto M, Parra F: Molecular cloning, sequencing and expression in Escherichia coli of the capsid protein gene from rabbit haemorrhagic disease virus (Spanish isolate AST/89). J Gen Virol 1994, 75:2409-2413.

141. Parra F, Boga JA, Marin MS, Casais R: The amino terminal sequence of VP60 from rabbit hemorrhagic disease virus supports its putative subgenomic origin. Virus Res 1993, 27:219-228.

142. Capucci L, Fallacara F, Grazioli S, Lavazza A, Pacciarini ML, Brocchi E: A further step in the evolution of rabbit hemorrhagic disease virus: the appearance of the first consistent antigenic variant. Virus Res 1998, 58:115-126.

143. Seal BS, Ridpath JF, Mengeling WL: Analysis of feline calicivirus capsid protein genes: identification of variable antigenic determinant regions of the protein. J Gen Virol 1993, 74:2519-2524.

144. Tohya Y, Yokoyama N, Maeda K, Kawaguchi Y, Mikami T: Mapping of antigenic sites involved in neutralization on the capsid protein of feline calicivirus. J Gen Virol 1997, 78:303-305.

145. Le Gall G, Arnauld C, Boilletot E, Morisse JP, Rasschaert D: Molecular epidemiology of rabbit haemorrhagic disease virus outbreaks in France during 1988 to 1995. J Gen Virol 1998, 79:11-16.

146. Schirrmeier H, Reimann I, Kollner B, Granzow H: Pathogenic, antigenic and molecular properties of rabbit haemorrhagic disease virus (RHDV) isolated from vaccinated rabbits: detection and characterization of antigenic variants. Arch Virol 1999, 144:719-735.

147. Matiz K, Ursu K, Kecskemeti S, Bajmocy E, Kiss I: Phylogenetic analysis of rabbit haemorrhagic disease virus (RHDV) strains isolated between 1988 and 2003 in eastern Hungary. Arch Virol 2006, 151:1659-1666.

148. Mclntosh MT, Behan SC, Mohamed FM, Lu Z, Moran KE, Burrage TG, Neilan JG, Ward GB, Botti G, Capucci L, Metwally SA: A pandemic strain of calicivirus threatens rabbit industries in the Americas. Virol J 2007, 4:96.

149. Oem JK, Lee KN, Roh IS, Lee KK, Kim SH, Kim HR, Park CK, Joo YS: Identification and characterization of rabbit hemorrhagic disease virus genetic variants isolated in Korea. J Vet Med Sci 2009, 71:1519-1523.

150. Tian L, Liao J, Li JW, Zhou WR, Zhang XL, Wang HN: Isolation and identification of a non-haemagglutinating strain of rabbit hemorrhagic disease virus from China and sequence analysis for the VP60 Gene. Virus Genes 2007, 35:745-752.

151. Grenfell BT, Pybus OG, Gog JR, Wood JL, Daly JM, Mumford JA, Holmes EC: Unifying the epidemiological and evolutionary dynamics of pathogens. Science 2004, 303:327-332.

152. Estes MK, Cohen J: Rotavirus gene structure and function. Microbiol Rev 1989, 53:410-449.

153. Jameel S, Zafrullah M, Ozdener MH, Panda SK: Expression in animal cells and characterization of the hepatitis E virus structural proteins. J Virol 1996, 70:207-216.

154. Caust J, Dyall-Smith ML, Lazdins I, Holmes $1 \mathrm{H}$ : Glycosylation, an important modifier of rotavirus antigenicity. Arch Virol 1987, 96:123-134.
155. Graff J, Zhou YH, Torian U, Nguyen H, St Claire M, Yu C, Purcell RH, Emerson SU: Mutations within potential glycosylation sites in the capsid protein of hepatitis $E$ virus prevent the formation of infectious virus particles. J Virol 2008, 82:1185-1194.

156. Guittre C, Baginski I, Le Gall G, Prave M, Trepo C, Cova L: Detection of rabbit haemorrhagic disease virus isolates and sequence comparison of the $\mathrm{N}$-terminus of the capsid protein gene by the polymerase chain reaction. Res Vet Sci 1995, 58:128-132.

157. Rasschaert D, Huguet S, Madelaine MF, Vautherot JF: Sequence and genomic organization of a rabbit hemorrhagic disease virus isolated from a wild rabbit. Virus Genes 1995, 9:121-132.

158. Viaplana $E$, Villaverde A: Microheterogeneity of p60 capsid protein and the encoding gene among contemporary isolates of rabbit hemorrhagic disease virus. Virus Genes 1996, 12:189-192.

159. Asgari S, Hardy JR, Cooke BD: Sequence analysis of rabbit haemorrhagic disease virus (RHDV) in Australia: alterations after its release. Arch Virol 1999, 144:135-145.

160. Moss SR, Turner SL, Trout RC, White PJ, Hudson PJ, Desai A, Armesto M, Forrester NL, Gould EA: Molecular epidemiology of Rabbit haemorrhagic disease virus. J Gen Virol 2002, 83:2461-2467.

161. van de Bildt MW, van Bolhuis GH, van Zijderveld F, van Riel D, Drees JM, Osterhaus AD, Kuiken T: Confirmation and phylogenetic analysis of rabbit hemorrhagic disease virus in free-living rabbits from the Netherlands. J Wildl Dis 2006, 42:808-812.

162. Yang L, Wang F, Hu B, Xue J, Hu Y, Zhou B, Wang D, Xu W: Development of an RT-PCR for rabbit hemorrhagic disease virus (RHDV) and the epidemiology of RHDV in three eastern provinces of China. J Virol Methods 2008, 151:24-29.

163. Hukowska-Szematowicz B, Pawlikowska M, Deptula W: Genetic variability of Czech and German RHD virus strains. Pol J Microbiol 2009, 58:237-245

164. Schuffenecker I, Ando T, Thouvenot D, Lina B, Aymard M: Genetic classification of "Sapporo-like viruses". Arch Virol 2001, 146:2115-2132.

165. Zheng DP, Ando T, Fankhauser RL, Beard RS, Glass RI, Monroe SS: Norovirus classification and proposed strain nomenclature. Virology 2006, 346:312-323.

166. Capucci L, Fusi P, Lavazza A, Pacciarini ML, Rossi C: Detection and preliminary characterization of a new rabbit calicivirus related to rabbit hemorrhagic disease virus but nonpathogenic. J Virol 1996, 70:8614-8623.

167. Forrester NL, Abubakr Ml, Abu Elzein EM, Al-Afaleq Al, Housawi FM, Moss SR, Turner SL, Gould EA: Phylogenetic analysis of rabbit haemorrhagic disease virus strains from the Arabian Peninsula: did RHDV emerge simultaneously in Europe and Asia? Virology 2006, 344:277-282.

168. Strive T, Wright JD, Robinson AJ: Identification and partial characterisation of a new Lagovirus in Australian wild rabbits. Virology 2009, 384:97-105.

169. Chasey D, Lucas MH, Westcott DG, Sharp G, Kitching A, Hughes SK: Development of a diagnostic approach to the identification of rabbit haemorrhagic disease. Vet Rec 1995, 137:158-160.

170. Collins BJ, White JR, Lenghaus C, Boyd V, Westbury HA: A competition ELISA for the detection of antibodies to rabbit haemorrhagic disease virus. Vet Microbiol 1995, 43:85-96.

171. Trout RC, Chasey D, Sharp G: Seroepidemiology of rabbit haemorrhagic disease (RHD) in wild rabbits (Oryctolagus cuniculus) in the United Kingdom. J Zool (Lond) 1997, 243:846-853

172. O'Keefe JS, Tempero JE, Motha MX, Hansen MF, Atkinsona PH: Serology of rabbit haemorrhagic disease virus in wild rabbits before and after release of the virus in New Zealand. Vet Microbiol 1999, 66:29-40.

173. Nagesha HS, McColl KA, Collins BJ, Morrissy CJ, Wang LF, Westbury HA: The presence of cross-reactive antibodies to rabbit haemorrhagic disease virus in Australian wild rabbits prior to the escape of virus from quarantine. Arch Virol 2000, 145:749-757.

174. Robinson AJ, Kirkland PD, Forrester RI, Capucci L, Cooke BD, Philbey AW: Serological evidence for the presence of a calicivirus in Australian wild rabbits, Oryctolagus cuniculus, before the introduction of rabbit haemorrhagic disease virus (RHDV): its potential influence on the specificity of a competitive ELISA for RHDV. Wildl Res 2002, 29:655-662.

175. Forrester NL, Boag B, Moss SR, Turner SL, Trout RC, White PJ, Hudson PJ, Gould EA: Long-term survival of New Zealand rabbit haemorrhagic disease virus RNA in wild rabbits, revealed by RT-PCR and phylogenetic analysis. J Gen Virol 2003, 84:3079-3086. 
176. Forrester NL, Trout RC, Gould EA: Benign circulation of rabbit haemorrhagic disease virus on Lambay Island, Eire. Virology 2007, 358:18-22.

177. Smid B, Valicek L, Rodak L, Stepanek J, Jurak E: Rabbit haemorrhagic disease: an investigation of some properties of the virus and evaluation of an inactivated vaccine. Vet Microbiol 1991, 26:77-85

178. Zheng T, Napier AM, Parkes JP, O'Keefe JS, Atkinson PH: Detection of RNA of rabbit haemorrhagic disease virus from New Zealand wild rabbits. Wildl Res 2002, 29:683-688.

179. Forrester NL, Boag B, Buckley A, Moureau G, Gould EA: Co-circulation of widely disparate strains of rabbit haemorrhagic disease virus could explain localised epidemicity in the United Kingdom. Virology 2009, 393:42-48.

180. Bergin IL, Wise AG, Bolin SR, Mullaney TP, Kiupel M, Maes RK: Novel calicivirus identified in rabbits, Michigan, USA. Emerg Infect Dis 2009, 15:1955-1962.

181. Le Gall-Recule G, Zwingelstein F, Fages MP, Bertagnoli S, Gelfi J, Aubineau J, Roobrouck A, Botti G, Lavazza A, Marchandeau S: Characterisation of a non-pathogenic and non-protective infectious rabbit lagovirus related to RHDV. Virology 2011, 410:395-402.

182. Capucci L, Nardin A, Lavazza A: Seroconversion in an industrial unit of rabbits infected with a non-pathogenic rabbit haemorrhagic disease-like virus. Vet Rec 1997, 140:647-650.

183. Chasey D, Trout RC, Edwards S: Susceptibility of wild rabbits (Oryctolagus cuniculus) in the United Kingdom to rabbit haemorrhagic disease (RHD). Vet Res 1997, 28:271-276

184. Strive T, Wright J, Kovaliski J, Botti G, Capucci L: The non-pathogenic Australian lagovirus RCV-A1 causes a prolonged infection and elicits partial cross-protection to rabbit haemorrhagic disease virus. Virology 2010, 398:125-134

185. Marchandeau S, Le Gall-Recule G, Bertagnoli S, Aubineau J, Botti G, Lavazza A: Serological evidence for a non-protective RHDV-like virus. Vet Res 2005, 36:53-62.

186. Abrantes J, Esteves PJ: Not-so-novel michigan rabbit calicivirus. Emerg Infect Dis 2010, 16:1331-1332.

187. Abrantes J, Esteves PJ, van der Loo W: Evidence for recombination in the major capsid gene VP60 of the rabbit haemorrhagic disease virus (RHDV). Arch Virol 2008, 153:329-335.

188. Forrester NL, Moss SR, Turner SL, Schirrmeier H, Gould EA: Recombination in rabbit haemorrhagic disease virus: possible impact on evolution and epidemiology. Virology 2008, 376:390-396.

189. Corbet GB: Taxonomy and origins. In The European rabbit. Edited by: Tompson HV, King CM. Oxford: Oxford Science Publications; 1994:1-6.

190. Lopez-Martinez N: Revisión sistemática y biostratigráfica de los Lagomorpha (Mammalia) del Terciario y Cuaternario de España. Volume 3: Memorias del Museo Paleontologico de la Universidad de Zaragoza 1989, (in Spanish).

191. Lopez-Martinez N: The Lagomorph fossil record and the origin of the European rabbit. In Lagomorph Biology: Evolution, Ecology and Conservation. Edited by: Alves PC, Ferrand N, Hackländer K. Berlin Heidelberg New York: Springer; 2008:27-46

192. Pages MV: Essai de reconstitution de l'histoire du lapin de garenne en Europe. Bull Mens Off Natl Chasse 1980, 13-21.

193. Cabrera A: Fauna Ibérica; mamíferos. Madrid: Museo Nacional de Ciencias Naturales; 1914.

194. Carneiro M, Ferrand N, Nachman MW: Recombination and speciation: loci near centromeres are more differentiated than loci near telomeres between subspecies of the European rabbit (Oryctolagus cuniculus). Genetics 2009, 181:593-606.

195. Queney G, Ferrand N, Weiss S, Mougel F, Monnerot M: Stationary distributions of microsatellite loci between divergent population groups of the European rabbit (Oryctolagus cuniculus). Mol Biol Evol 2001, 18:2169-2178

196. Esteves PJ, Lanning D, Ferrand N, Knight KL, Zhai SK, van der Loo W: Allelic variation at the $\mathrm{VHa}$ locus in natural populations of rabbit (Oryctolagus cuniculus, L.). J Immunol 2004, 172:1044-1053.

197. Ferrand N, Branco M: The evolutionary history of the European rabbit (Oryctolagus cuniculus): major patterns of population differentiation and geographic expansion inferred from protein polymorphism. In Phylogeography of southern European refugia. Edited by: Weiss S, Ferrand N. Berlin Heidelberg New York: Springer; 2007:207-235.
198. Surridge AK, van der Loo W, Abrantes J, Carneiro M, Hewitt GM, Esteves PJ: Diversity and evolutionary history of the MHC DQA gene in leporids. Immunogenetics 2008, 60:515-525.

199. van der Loo W, Ferrand N, Soriguer RC: Estimation of gene diversity at the $b$ locus of the constant region of the immunoglobulin light chain in natural populations of European rabbit (Oryctolagus cuniculus) in Portugal, Andalusia and on the Azorean Islands. Genetics 1991, 127:789-799.

200. van der Loo W, Mougel F, Bouton C, Sanchez MS, Monnerot M: The allotypic patchwork pattern of the rabbit IGKC1 allele b5wf: genic exchange or common ancestry? Immunogenetics 1999, 49:7-14.

201. Carneiro M, Afonso S, Geraldes A, Garreau H, Bolet G, Boucher S, Tircazes A, Queney G, Nachman MW, Ferrand N: The genetic structure of domestic rabbits. Mol Biol Evol 2011, 28:1801-1816.

202. Ferrand N: Inferring the Evolutionary History of the European Rabbit (Oryctolagus cuniculus) from Molecular Markers. In Lagomorph Biology: Evolution, Ecology and Conservation. Edited by: Alves PC, Ferrand N, Hackländer K. Berlin Heidelberg New York: Springer; 2008:47-63.

203. Fenner F, Ratcliffe FN: Myxomatosis. Cambridge: Cambridge University Press; 1965.

204. Elsworth P, Cooke B: Co-evolution of wild rabbits (Oryctolagus cuniculus) and RHDV: resistance and virulence. 14th Australasian Vertebrate Pest Conference Canberra, Australia; 2008

205. Cooke BD, Elsworth PG, Berman DM, McPhee SR, Kovalivski J, Mutze GJ, Sinclair RG, Capucci L: Rabbit haemorrhagic disease: wild rabbits show resistance to infection with Czech strain 351 RHDV initially released in Australia. Submitted to Australian Wool Innovations and Meat and Livestock Australia. Canberra: Invasive Animals Cooperative Research Centre; 2007.

206. Arguello Villares JL: Viral haemorrhagic disease of rabbits: vaccination and immune response. Rev Sci Tech 1991, 10:471-480.

207. Boga JA, Martin Alonso JM, Casais R, Parra F: A single dose immunization with rabbit haemorrhagic disease virus major capsid protein produced in Saccharomyces cerevisiae induces protection. J Gen Virol 1997, 78:2315-2318.

208. Farnos O, Boue O, Parra F, Martin-Alonso JM, Valdes O, Joglar M, Navea L, Naranjo $P$, Lleonart R: High-level expression and immunogenic properties of the recombinant rabbit hemorrhagic disease virus VP60 capsid protein obtained in Pichia pastoris. J Biotechnol 2005, 117:215-224.

209. Mikschofsky H, Hammer M, Schmidtke J, König P, Keil G, Schirrmeier H, Schmidt K, Broer I: Optimization of growth performance of freshly induced carrot suspensions concerning PMP production. In Vitro Cell Dev Biol Plant 2009, 45:740-749.

210. Castanon S, Marin MS, Martin-Alonso JM, Boga JA, Casais R, Humara JM, Ordas RJ, Parra F: Immunization with potato plants expressing VP60 protein protects against rabbit hemorrhagic disease virus. J Virol 1999, 73:4452-4455.

211. Mikschofsky H, Schirrmeier H, Keil GM, Lange B, Polowick PL, Keller W, Broer I: Pea-derived vaccines demonstrate high immunogenicity and protection in rabbits against rabbit haemorrhagic disease virus. Plant Biotechnol J 2009, 7:537-549.

212. Fernandez-Fernandez MR, Mourino M, Rivera J, Rodriguez F, Plana-Duran J, Garcia JA: Protection of rabbits against rabbit hemorrhagic disease virus by immunization with the VP60 protein expressed in plants with a potyvirus-based vector. Virology 2001, 280:283-291.

213. Gil F, Titarenko E, Terrada E, Arcalis E, Escribano JM: Successful oral primeimmunization with VP60 from rabbit haemorrhagic disease virus produced in transgenic plants using different fusion strategies. Plant Biotechnol J 2006, 4:135-143.

214. Perez-Filgueira DM, Resino-Talavan P, Cubillos C, Angulo I, Barderas MG, Barcena J, Escribano JM: Development of a low-cost, insect larvae-derived recombinant subunit vaccine against RHDV. Virology 2007, 364:422-430.

215. Fernandez E, Toledo JR, Chiong M, Parra F, Rodriguez E, Montero C, Mendez L, Capucci L, Farnos O: Single dose adenovirus vectored vaccine induces a potent and long-lasting immune response against rabbit hemorrhagic disease virus after parenteral or mucosal administration. Vet Immunol Immunopathol 2011, 142:179-188.

216. Bertagnoli S, Gelfi J, Le Gall G, Boilletot E, Vautherot JF, Rasschaert D, Laurent S, Petit F, Boucraut-Baralon C, Milon A: Protection against myxomatosis and rabbit viral hemorrhagic disease with recombinant 
myxoma viruses expressing rabbit hemorrhagic disease virus capsid protein. J Virol 1996, 70:5061-5066.

217. Bertagnoli S, Gelfi J, Petit F, Vautherot JF, Rasschaert D, Laurent S, Le Gall G, Boilletot E, Chantal J, Boucraut-Baralon C: Protection of rabbits against rabbit viral haemorrhagic disease with a vaccinia-RHDV recombinant virus. Vaccine 1996, 14:506-510

218. Fischer L, Le Gros FX, Mason PW, Paoletti E: A recombinant canarypox virus protects rabbits against a lethal rabbit hemorrhagic disease virus (RHDV) challenge. Vaccine 1997, 15:90-96

219. Barcena J, Morales M, Vazquez B, Boga JA, Parra F, Lucientes J, PagesMante A, Sanchez-Vizcaino JM, Blasco R, Torres JM: Horizontal transmissible protection against myxomatosis and rabbit hemorrhagic disease by using a recombinant myxoma virus. I Virol 2000, 74:1114-1123.

220. Calvete C, Estrada R, Lucientes J, Osacar JJ, Villafuerte R: Effects of vaccination against viral haemorrhagic disease and myxomatosis on long-term mortality rates of European wild rabbits. Vet Rec 2004, 155:388-392.

221. Calvete C, Estrada R, Osacar JJ, Lucientes J, Villafuerte R: Short-term negative effects of vaccination campaigns against myxomatosis and viral hemorrhagic disease (VHD) on the survival of European wild rabbits. J Wild Manage 2004, 68:198-205.

222. Manual OT: Rabbit haemorrhagic disease. Office International des Epizooties 2010, 1-15.

223. Cabezas S, Calvete C, Moreno S: Vaccination success and body condition in the European wild rabbit: applications for conservation strategies. $J$ Wild Manage 2006, 70:1125-1131.

224. Farnos O, Rodriguez M, Chiong M, Parra F, Boue O, Lorenzo N, Colas M, Lleonart R: The recombinant rabbit hemorrhagic disease virus VP60 protein obtained from Pichia pastoris induces a strong humoral and cellmediated immune response following intranasal immunization in mice. Vet Microbiol 2006, 114:187-195.

225. Martin-Alonso JM, Castanon S, Alonso P, Parra F, Ordas R: Oral immunization using tuber extracts from transgenic potato plants expressing rabbit hemorrhagic disease virus capsid protein. Transgenic Res 2003, 12:127-130.

226. Peshev $R$, Christova $L$ : The efficacy of a bivalent vaccine against pasteurellosis and rabbit haemorrhagic disease virus. Vet Res Commun 2003, 27:433-444.

227. El Mehdaoui S, Touze A, Laurent S, Sizaret P-Y, Rasschaert D, Coursaget P: Gene transfer using recombinant rabbit hemorrhagic disease virus capsids with genetically modified dna encapsidation capacity by addition of packaging sequences from the 11 or 12 protein of human papillomavirus type 16. J Virol 2000, 74:10332-10340.

228. Peacey M, Wilson S, Baird MA, Ward VK: Versatile RHDV virus-like particles: incorporation of antigens by genetic modification and chemical conjugation. Biotechnol Bioeng 2007, 98:968-977.

229. Peacey M, Wilson S, Perret R, Ronchese F, Ward VK, Young V, Young SL, Baird MA: Virus-like particles from rabbit hemorrhagic disease virus can induce an anti-tumor response. Vaccine 2008, 26:5334-5337.

230. Win SJ, Ward VK, Dunbar PR, Young SL, Baird MA: Cross-presentation of epitopes on virus-like particles via the $\mathrm{MHC}$ I receptor recycling pathway. Immunol Cell Biol 2011, 89:681-688.

231. Crisci E, Almanza H, Mena I, Cordoba L, Gomez-Casado E, Caston JR, Fraile L, Barcena J, Montoya M: Chimeric calicivirus-like particles elicit protective anti-viral cytotoxic responses without adjuvant. Virology 2009, 387:303-312.

232. Young SL, Wilson M, Wilson S, Beagley KW, Ward V, Baird MA: Transcutaneous vaccination with virus-like particles. Vaccine 2006 24:5406-5412

233. Tunon MJ, Sanchez-Campos S, Garcia-Ferreras J, Alvarez M, Jorquera F, Gonzalez-Gallego J: Rabbit hemorrhagic viral disease: characterization of a new animal model of fulminant liver failure. J Lab Clin Med 2003, 141:272-278

234. Tunon MJ, Alvarez M, Culebras JM, Gonzalez-Gallego J: An overview of animal models for investigating the pathogenesis and therapeutic strategies in acute hepatic failure. World I Gastroenterol 2009, 15:3086-3098.

235. Sanchez-Campos S, Alvarez M, Culebras JM, Gonzalez-Gallego J, Tunon MJ: Pathogenic molecular mechanisms in an animal model of fulminant hepatic failure: rabbit hemorrhagic viral disease. J Lab Clin Med 2004, 144:215-222.
236. San-Miguel B, Alvarez M, Culebras JM, Gonzalez-Gallego J, Tunon MJ: Nacetyl-cysteine protects liver from apoptotic death in an animal model of fulminant hepatic failure. Apoptosis 2006, 11:1945-1957.

237. Garcia-Lastra R, San-Miguel B, Crespo I, Jorquera F, Alvarez M, GonzalezGallego J, Tunon MJ: Signaling pathways involved in liver injury and regeneration in rabbit hemorrhagic disease, an animal model of virallyinduced fulminant hepatic failure. Vet Res 2010, 41:2.

238. Crespo I, Miguel BS, Laliena A, Alvarez M, Culebras JM, Gonzalez-Gallego J, Tunon MJ: Melatonin prevents the decreased activity of antioxidant enzymes and activates nuclear erythroid 2-related factor 2 signaling in an animal model of fulminant hepatic failure of viral origin. $J$ Pineal Res 2010, 49:193-200.

239. Tunon MJ, San Miguel B, Crespo I, Jorquera F, Santamaria E, Alvarez M, Prieto J, Gonzalez-Gallego J: Melatonin attenuates apoptotic liver damage in fulminant hepatic failure induced by the rabbit hemorrhagic disease virus. J Pineal Res 2011, 50:38-45.

240. Bernal W, Auzinger G, Dhawan A, Wendon J: Acute liver failure. Lancet 2010, 376:190-201

241. Ferreira PG, Costa ESA, Monteiro E, Oliveira MJ, Aguas AP: Liver enzymes and ultrastructure in rabbit haemorrhagic disease (RHD). Vet Res Commun 2006, 30:393-401.

242. Ferreira PG, Costa-e-Silva A, Oliveira MJ, Monteiro E, Cunha EM, Aguas AP: Severe leukopenia and liver biochemistry changes in adult rabbits after calicivirus infection. Res Vet Sci 2006, 80:218-225.

243. Ramiro-Ibáñez F, Martín-Alonso JM, García Palencia P, Parra F, Alonso C: Macrophage tropism of rabbit hemorrhagic disease virus is associated with vascular pathology. Virus Res 1999, 60:21-28.

doi:10.1186/1297-9716-43-12

Cite this article as: Abrantes et al:: Rabbit haemorrhagic disease (RHD) and rabbit haemorrhagic disease virus (RHDV): a review. Veterinary Research 2012 43:12.

\section{Submit your next manuscript to BioMed Central and take full advantage of:}

- Convenient online submission

- Thorough peer review

- No space constraints or color figure charges

- Immediate publication on acceptance

- Inclusion in PubMed, CAS, Scopus and Google Scholar

- Research which is freely available for redistribution

Submit your manuscript at www.biomedcentral.com/submit
C Biomed Central 